\title{
THE ARCHAEOBOTANY OF NEOLITHIC AND BRONZE AGE CRETE: SYNTHESIS AND PROSPECTS
}

\author{
by Alexandra Livarda ${ }^{1}$ and Georgia Kotzamani ${ }^{2}$
}

1. Department of Archaeology, University of Nottingham

2. Ephorate of Palaeoanthropology-Speleology of Southern Greece, Ministry of Culture

\begin{abstract}
This paper explores the full potential of archaeobotanical research in the investigation of issues such as agricultural practices and resource management and mobilisation in shaping the social dynamics of Neolithic and Bronze Age Crete, through a synthesis for the first time of all available archaeobotanical information to date. To this body of data new information is added from six sites: Kephala Petras, Pryniatikos Pyrgos, Aghia Fotia, Knossos Little Palace North, Sissi and Zominthos. A comprehensive methodology is devised using three units of analysis to allow an in-depth study, firstly of the quality of the available dataset and secondly of its content. A total of 80 archaeobotanical records, compiled in one database, are examined in the light of the methods employed for their sampling, recovery and processing. The reliability of the current dataset is assessed, highlighting shortcomings; methodological issues are addressed to improve its quality. These records are then analysed according to their temporal, spatial and contextual distribution across the island. A synthesis of the full resource base, including cereals, legumes, fruits, nuts, condiments and wild species, is conducted, providing a contextualised picture of their availability and use, and identifying lacunae and interpretational potential. On these bases a research agenda is set and future research priorities and new approaches are suggested that place archaeobotany in the core of current archaeological discourse on social models, practices and meanings for prehistoric Crete.
\end{abstract}

\section{INTRODUCTION}

Agricultural management and control over food resources have been crucial points in debates on social organisation during the long history of Cretan archaeology (e.g. A.C. Renfrew 1972; Halstead and O'Shea 1982; Galaty, Nakassis and Parkinson 2011). The introduction/use of new food plants, the adoption of intensive or extensive agricultural regimes, specialisation and diversification of crops, surplus production and storage, control over distribution and conversion of food surplus to political capital have been key issues in the endeavour to understand the changing social structures in the island, particularly for the Bronze Age. Despite the importance of such issues and the extensive archaeological work in Crete, primary bio-archaeological material and especially plants are conspicuously absent from such debates. Jones (1987) and Hansen (1988), in their work in Greece and the Aegean, have aptly demonstrated the potential of plant remains to address mainstream archaeological questions. Sarpaki (e.g. 2000; 2012a) has also repeatedly emphasised the importance of the collection of this class of material, pointing out that, given the lack of legislation concerning bio-archaeological research in Greece, it is down to the most conscientious archaeologists to circumvent the largely standard belief that 'what is not seen by the naked eye is not present' (Sarpaki 2012a, 37). Despite the great efforts of several archaeobotanists and a few other archaeologists (e.g. Halstead 2004; Hamilakis 1996), the significance of this line of evidence seems to be still poorly understood and plants are often considered as a secondary line of evidence. Thus the aim of this article is to offer a new frame of reference for understanding the use of plant resources from the Neolithic to the end of the Bronze Age in Crete, and to provide the basis for a reexamination of their role in the radical political, social and economic changes attested in the island.

Investigations on the state of archaeobotanical research in Crete have been attempted until now only as part of general studies for the whole or part of modern-day Greece (Vickery 1936; Hansen 1988; 2000; Kroll 1991; Megaloudi 2006; Valamoti 2009), including no more than 14 sites from Crete, but a comprehensive synthesis of Cretan archaeobotany has been outside their scope. 
More recently, Sarpaki (2012a) contributed a valuable overview of the evidence of Neolithic Knossos, followed by an examination of all lines of bio-archaeological evidence and other scientific analyses on the presence and cultivation of vine and olive, drawing on about 40 archaeobotanical studies in Crete.

This study brings together and synthesises for the first time all available archaeobotanical evidence ${ }^{\boldsymbol{T}}$ from Crete and adds new data from six sites: Kephala Petras, Pryniatikos Pyrgos, Aghia Fotia, Knossos Little Palace North, Sissi and Zominthos. All sites are dated to the Bronze Age and Kephala Petras additionally provides the second Neolithic archaeobotanical assemblage for the whole of Crete. A systematic assessment of both the quality and content of the available dataset is presented, highlighting strengths, weaknesses, general trends and lacunae. The potential of new methodological pathways to enhance the current archaeological debates is outlined and a research agenda for the archaeobotany of prehistoric Crete is set. Our endeavour is ultimately to provide a solid basis that will allow contextualisation of all new archaeobotanical work in Crete while at the same time serving as a reference point for archaeobotanists working in Greece and a thought-provoking exercise for all archaeologists in the field.

\section{METHODOLOGY}

All available archaeobotanical reports and general archaeological studies that mention spot finds of plant remains from Crete were accessed and recorded through extensive bibliographical research and liaison with archaeobotanists working in Crete. Three units of analysis were selected for this study: the site, the reference and the record. With the term 'site' we refer to locations of excavations. So, for instance, Knossos may include several 'sites' as various excavations were conducted in different parts of the town, such as at the Little Palace, the Unexplored Mansion, the Caravanserai and so on. 'References' indicate the publications including archaeobotanical material of a site, which may have resulted from several excavation projects or teams. However, if there are several publications referring to the same material these are noted but are recorded together as one 'reference'. If a publication mentions material from several sites then these are recorded as separate references. The term 'record' refers to the smallest unit of analysis and is a subset of the 'reference'. In particular, if a reference includes archaeobotanical information from multiple periods within a site these represent separate 'records'. Different samples and contexts of the same date in a reference have been amalgamated in one record if they derive from the same broader site type (e.g. a palace) and only certain notes were taken from these smaller units (see below), as a full sample-by-sample analysis was beyond the scope of this study. So, for instance, Malia represents one 'site', two 'references': Chapouthier and Charbonneaux 1928 and Sarpaki 2007; and four 'records': Chapouthier and Charbonneaux 1928 on the Neopalatial elite sector, one record; and Sarpaki 2007 on Protopalatial, 'Neopalatial/onwards' and Postpalatial town, three records (see details on the period classification below).

For each record we noted the presence of all plant remains, the plant part preserved, the security of the identification and the preservation mode. We also noted species that occur in substantial quantities in at least one sample in a given record, which often can be translated as deliberately collected/used rather than occurring by chance. To do so, we made a note of species that were found in quantities of more than 350 items and/or more than 100 but less than 350 items, counting the minimum number of individuals (MNI). The choice of these numerical thresholds follows Van der Veen and Fieller (1982) on the required quantities of plant remains per sample to provide a $95 \%$ chance of estimating a percentage content of a species to within $5 \%$ accuracy (in absolute terms), assuming an infinite 'target population'.

Sampling and archaeobotanical information was gathered for each reference as indicated in Table 1. Regarding chronology a note was made as given in the reference, including the actual

1 Macro-remains, such as seeds, fruits, chaff, etc., except charcoal. 
Table 1. Synopsis of the information recorded in the database.

Site/reference information

Site name

Area (Prefecture)

Geographical location (latitude/longitude)

Site type

Chronological period

Numerical dating

Full Reference

Date of excavation

Date of publication

\title{
Sampling information
}

Sampling strategy (spotfind, impression, judgement, systematic)

Total number of samples

Volume of soil sample (minimum, maximum, average, total)

Recovery method (flotation, wet-sieving, handpicking)

Minimum mesh size (if flotation, wet-sieving)

\author{
Archaeobotanical information \\ Preservation modes of plant remains \\ Presence of crop in $>350$ items in at least one sample (yes/no) \\ Presence of crop in $>100<350$ items in at least one sample (yes/no) \\ Presence of cereals (yes/no) \\ Presence of pulses (yes/no) \\ Presence of fruit/nut (yes/no) \\ Presence of wild species (yes/no) \\ Quantification mode
}

numerical dating if that was available. On this basis and using the low chronology for Minoan Crete (see Tartaron 2008, 84), each record was then assigned to one of the following periods: Aceramic, Early, Middle, Late and Final Neolithic, Prepalatial, Protopalatial, Neopalatial, Final Palatial and Postpalatial. Those records that fell in between some categories were classified as Pre/Protopalatial, Proto/Neopalatial, Neopalatial/onwards or simply Minoan. Each record was then assigned to a general site type, according to the available archaeological and contextual information, to investigate any potential associations between certain taxa and socio-economic units. The classification employed is as follows: hamlet/small settlement, building complex, medium/large settlement, town, villa, elite/palatial, industrial, sanctuary, burial/cemetery and cave. All of the data were stored in an Access Database.

\section{THE DATABASE}

In total 80 records are included in the database, corresponding to 61 references and 44 sites. Fig. 1 illustrates the uneven distribution of records across the different periods. The Neopalatial period is the best-represented one, while all Neolithic phases seem to be archaeobotanically poorly understood. In terms of the geographical spread of sites the western part of Crete is the least represented archaeobotanically, with most studies deriving from sites on or near the north coast of the central and eastern part of the island (Fig. 2). This overall picture is largely a reflection, on a much-reduced scale, of the geographical coverage of archaeological work in Crete, which in turn reflects roughly the existing settlement pattern (e.g. Shelmerdine 2008). The distribution of records in different site types by period is indicated in Fig. 3. Plant remains are spread across all 

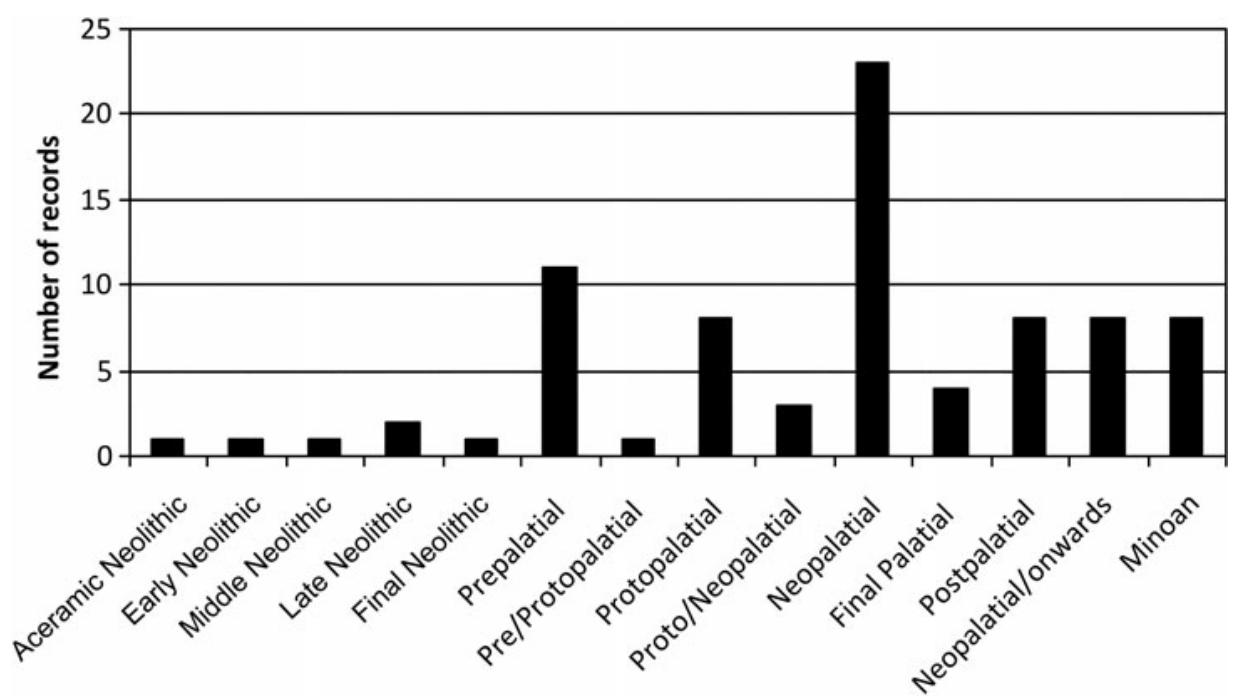

Fig. 1. The number of archaeobotanical records across the different Neolithic and Bronze Age phases.
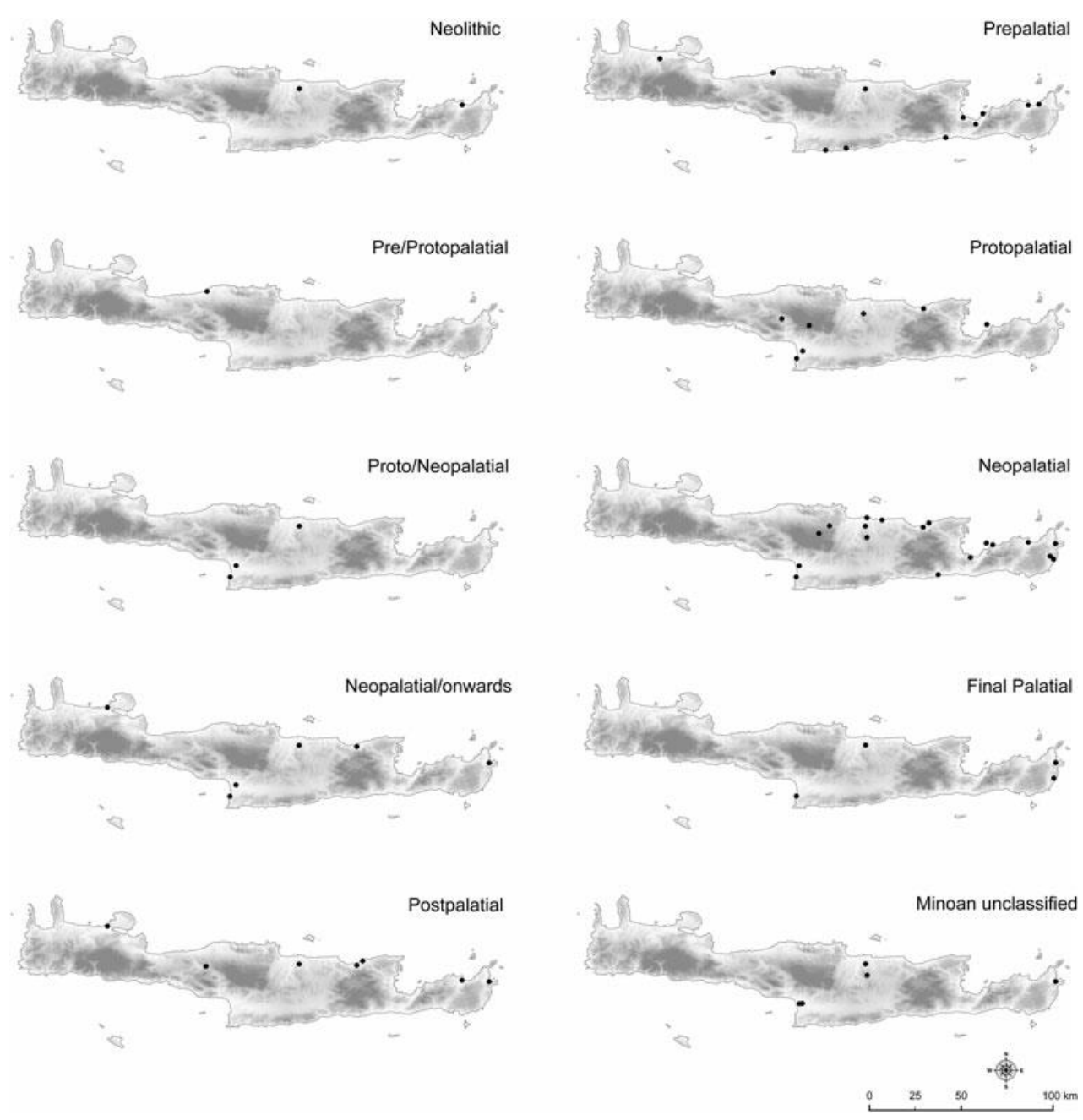

Fig. 2. Geographical distribution of archaeobotanical records in each period. 


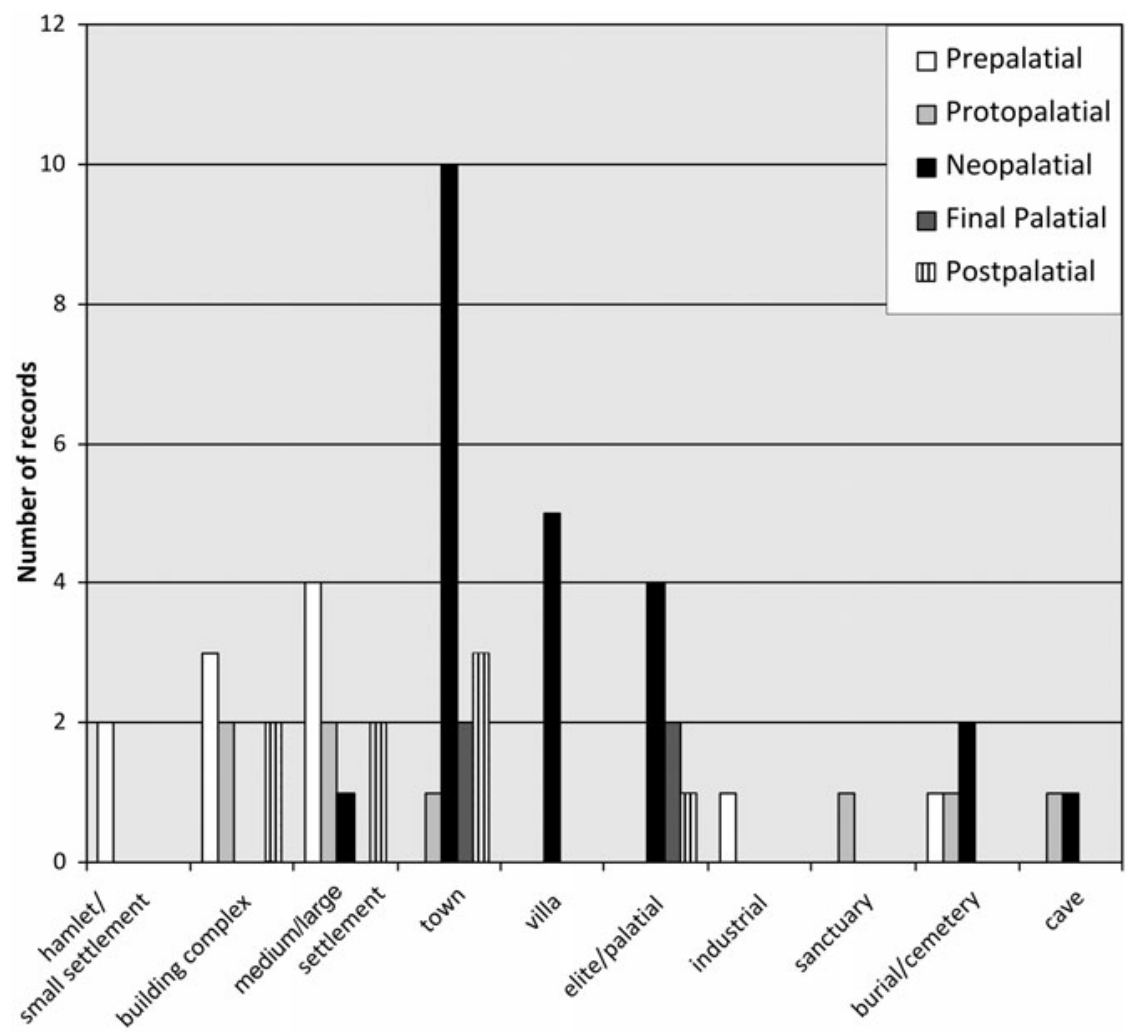

Fig. 3. The number of archaeobotanical records across different site types in each Bronze Age phase.

site types, but sanctuaries, industrial sites, caves and hamlets/small settlements have the fewest records.

\section{DATA QUALITY}

The quality of the dataset is investigated here in order to assess its reliability and highlight its strengths and weaknesses. The records are divided into spot finds and those resulting from archaeobotanically targeted sampling and/or study (Fig. 4).

\section{Spot finds}

All chance find records appear as notes in older archaeological studies (Fig. 5) and most of them lack detailed dating. Plant macro-remains were spotted already during the first excavations in Crete, their mention often prompted by their sheer quantity, as in the case of the large amounts of cereals and legumes from Knossos mentioned by A. Evans (e.g. 1928, 54; 1935, 621-2) or later from Trypiti by Vasilakis $(1989,54)$. Regrettably, in many cases this material was not kept, which given its apparent quality (good preservation, large quantities, often clearly separately stored crops) could have allowed new interpretations to be achieved by its re-examination.

The fact that no archaeobotanist had the opportunity to study these finds raises two issues of concern. The first is the security of the identification to species level, as it was normally down to the workers or some archaeologists to do this according to naked-eye observations. Indicative is the case of the crop contained in a pithos in the south room of the Lapidary's Workshop at

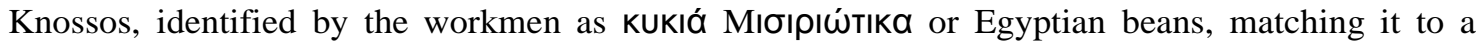




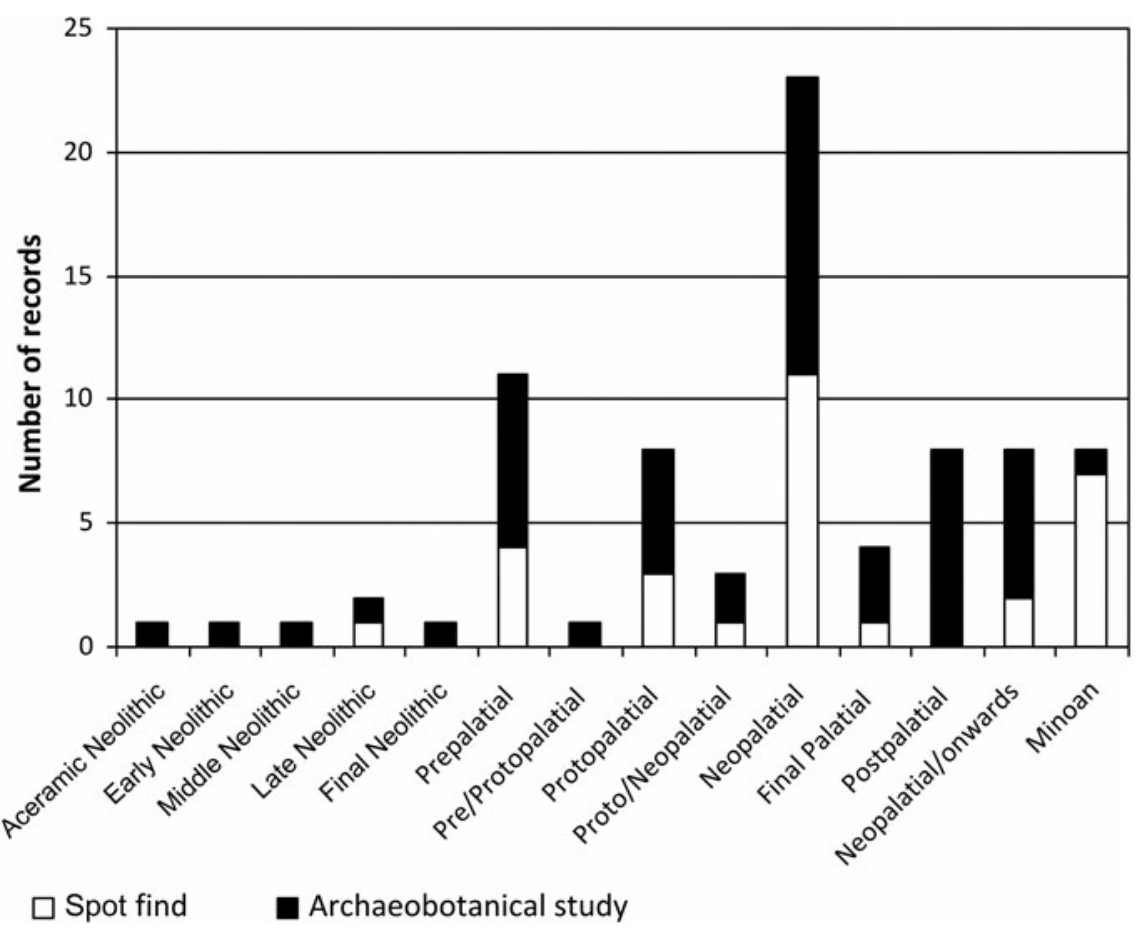

Fig. 4. The number of records of spot finds and archaeobotanical studies in each period.

variety of small fava beans imported to Crete from Alexandria at the end of the nineteenth century (A.J. Evans 1901, 20-1). In reality, archaeobotanical identifications can be very difficult as oftentimes species of the same genus or different subspecies can be distinguished only by close stereoscopic examination. Such detailed archaeobotanical work has allowed, for instance, the reidentification of the pea (Pisum sativum L.) from the Unexplored Mansion at Knossos as

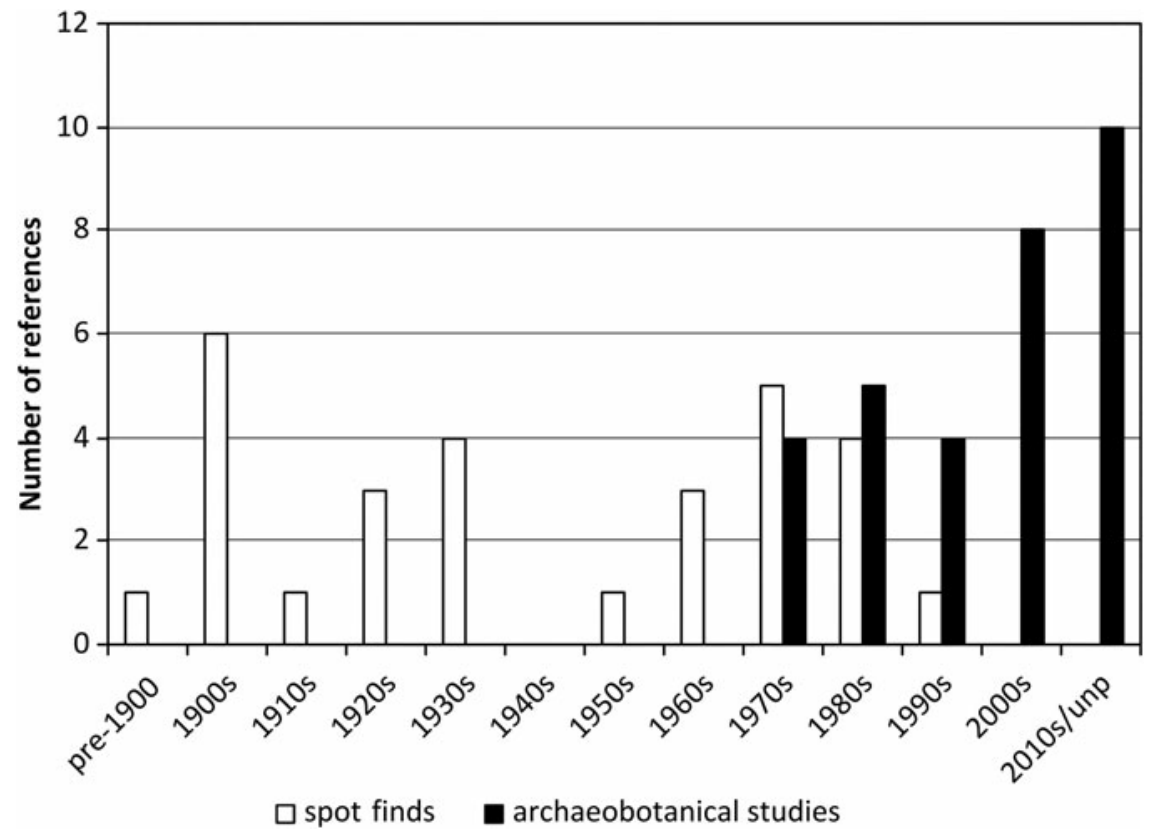

Fig. 5. The number of references of spot finds and archaeobotanical studies over time (unp = unpublished). 
Lathyrus ochrus (L.) DC., a rarer type of legume still cultivated in different parts of Greece (Jones 1992). Thus, this earlier information of chance finds needs to be treated with utmost caution. The second point of concern is more serious and relates to preservation issues. Unless a reference clearly states that the plant remains are carbonised, their antiquity cannot be judged. Particularly in cases of small quantities of uncharred remains (in Aegean contexts), these may represent modern intrusions, as plants decay unless they are turned to a biologically inert form (carbonisation or mineralisation) or, much more rarely in Mediterranean environments, are preserved in conditions without oxygen (waterlogged).

The balance between spot finds and archaeobotanical studies to favour the latter changed in the 1980s. The latest published archaeobotanical chance find is in Zois 1992, reporting on the 1991excavation of Early Minoan Vasiliki Ierapetras.

\section{Archaeobotanical studies}

Fifty records refer to archaeobotanical studies (Fig. 4). Such references appear in the 1970s but they remain relatively few, portraying a rather disappointing overall picture (Fig. 5). Naturally, the 2010s are still incomplete and some more records will probably be added from material currently under study and new excavation projects. Noticeably, most archaeobotanical studies are published with a long lag after the end of the excavation, often due to the long delay in receiving stratigraphic/dating information without which archaeobotanical work cannot be completed. More importantly, this lag demonstrates the lack of tight integration of archaeobotanical work into archaeological projects, which is a matter of serious concern.

The sampling strategy and the total number of bio-archaeological samples, relating to the spatial and temporal archaeobotanical coverage of a site, are considered first to assess the quality of archaeobotanical studies. Of the 31 references, three refer to material taken solely from casts (impressions), five ${ }^{2}$ report on material collected in a largely systematic manner, and the rest (23) are based on samples collected according to the judgement of the archaeologists. Impressions provide only qualitative information but when used in conjunction with controlled contextual data they can offer useful insights into past activities (e.g. Jones and Schofield 2006). The most complete and informative data are those retrieved by systematic sampling, referring to the collection of samples from every undisturbed excavation unit, as they allow accounting for spatial variation and are not based on already formed assumptions on the use of space. Serious attempts at systematic sampling have been conducted at Priniatikos Pyrgos, Kephala Petras, Pseira (Block AF), the Mochlos coastal plain and $\mathrm{Sissi}^{3}$, from where in total 174, 147, 55, 115 and 985 samples respectively were collected and processed by flotation. The differences in the number of samples essentially reflect the extent of the excavated area of each site relevant to the period of interest here.

The data quality of these five sites, however, differs in a very important parameter, the volume of soil samples. In Priniatikos Pyrgos and Kephala Petras the maximum volume of a sample -16 and 8 litres respectively - was particularly low, which impacted on the quantity of the material retrieved, and consequently on the breadth of the possible interpretations. At Pseira and Mochlos the average soil volume was 15 litres, while at Sissi it was about 40 to 60 litres after dry-sieving, which is the standard volume that can ensure the potential recovery of statistically significant quantities of material (according to the authors' experience and based on instructions initially taught by Prof. G. Jones). Dry-sieving, although lamentably rarely adopted for the processing of bio- archaeological samples, is very important because it ensures the careful recovery of fragile

\footnotetext{
2 A sixth one is currently under study from Palaikastro Building 1 (Sarpaki pers. comm.).

3 At Pseira soil samples were collected systematically within rooms; at Sissi systematic sampling was implemented after the second season of the excavation; at Priniatikos Pyrgos and Mochlos systematic strategy was implemented in principle although a few contexts were left out in parts of the excavation area. Note that at Pryniatikos Pyrgos only the Early Minoan phases have been studied and hence considered here.

4 Molloy et al. forthcoming and Kotzamani unpublished data.
} 
organic material, as large pottery fragments, bones and stones that could cause damage during processing with water are removed.

The minimum sieve size used in flotation also has an effect on the range of the recovered material, particularly of wild species that can be minuscule in size. We suggest that an aperture of at least $0.3 \mathrm{~mm}$ is necessary for the collection of most material. Of the five sites sampled systematically it was only at Priniatikos Pyrgos that a larger aperture sieve $(0.5 \mathrm{~mm})$ was used, which nevertheless can be considered small enough to retain a substantial proportion of the smaller items. Overall, therefore, of these sites, Sissi seems to be the one that best fulfils the criteria that ensure potentially the highest data quality.

Quantity is another matter of concern. Of the existing records, 13 have so far yielded at least one sample with a statistically significant number of charred plant remains (Table 2). Large concentrations of plant remains in a sample can help establish, for instance, which species were deliberately cultivated, and provide insights into the agricultural economy of a site, such as sowing time, irrigation techniques, and intensity of the cultivation regime, which in turn can illuminate issues of technology and social perceptions and organisation. Often, though, even when many samples of substantial volume are collected, archaeobotanical material may simply not be present. We believe that this can become either a problem or an asset to an archaeological project according to the approach adopted. The most common approach is the collection of samples according to the judgement of the archaeologists from 'promising' contexts, as an effective, midway solution that can employ archaeobotanical expertise without much reducing the excavation pace. In contrast, we believe that it is exactly this scenario that can lead to the most unprofitable situations in both practical and research terms. Time and money are invested in equipment and labour for bio-archaeological work and, unless there is a lucky 'hit', the plant remains recovered may be too few to contribute significantly to the archaeological interpretations of the site, which can, perhaps justifiably, lead to a depreciation of the potential of archaeobotanical work. Most importantly, however, this situation highlights the difficulties in judging on site which contexts both are undisturbed and may yield plant remains. The absence or low occurrence of archaeobotanical material can become meaningful when the whole excavated area has been examined for all lines of evidence in a systematic manner so that this information can be incorporated into a holistic appreciation of different uses of space, areas of low and high activities and so forth.

\section{BOTANICAL EVIDENCE AND RESEARCH QUESTIONS: CURRENT STATE OF AFFAIRS}

In this section all available archaeobotanical information is synthesised by plant type, addressing relevant research questions.

\section{Cereals}

Fully domesticated cereals are present in Crete since the Early Neolithic (Sarpaki 2009a). Wheat and barley seem to be of equal importance throughout the study period (Fig. 6). Since the Aceramic period most major cereals are present: glume wheat, including einkorn and emmer, free-threshing wheat, hulled and naked barley. Of the glume wheats, emmer appears to be the most common throughout and it is also found stored in the Late Minoan II storeroom $\mathrm{P}$ of the Unexplored Mansion at Knossos (Jones 1984). The early occurrence of free-threshing wheat (Triticum turgidum/aestivum) is quite impressive, considering current knowledge for the Aegean. It is next encountered at the eastern sector of Middle Minoan I-Middle Minoan IIB Monastiraki, in Neopalatial Aghia Triada and Ourania cave and in Final Palatial Unexplored Mansion at Knossos (Fig. 6), and is present in three out of the five sites where large quantities and stored cereals have been recovered (Table 2). Free-threshing wheat, with its good bread- making qualities, allows easier large-scale threshing and processing compared with glume 
Table 2. Summary of the Neolithic and Bronze Age assemblages from Crete with substantial amounts of archaeobotanical material.

\begin{tabular}{|c|c|c|c|}
\hline Record & Publication & $\begin{array}{l}>350 \text { items in at } \\
\text { least } 1 \text { sample }\end{array}$ & $\begin{array}{l}>100<350 \text { items in } \\
\text { at least } 1 \text { sample }\end{array}$ \\
\hline $\begin{array}{l}\text { Aceramic Neolithic } \\
\text { Knossos }\end{array}$ & $\begin{array}{l}\text { Evans et al. 1964; Warren } \\
\text { et al.1968; Sarpaki 2009a }\end{array}$ & Triticum aestivum/turgidum & Lens sp. \\
\hline $\begin{array}{l}\text { Prepalatial } \\
\text { Chamalevri }\end{array}$ & Sarpaki 1999 & possibly Olea europaea & $\begin{array}{l}\text { possibly Olea } \\
\text { europaea }\end{array}$ \\
\hline $\begin{array}{l}\text { Protopalatial } \\
\text { Monastiraki } 1\end{array}$ & Sarpaki and Kanta 2011 & $\begin{array}{l}\text { possibly Vitis vinifera } \\
\text { and various legumes }\end{array}$ & $?$ \\
\hline Monastiraki 2 & $\begin{array}{l}\text { Fiorentino and Solinas } \\
2006\end{array}$ & $\begin{array}{l}\text { Vitis vinifera; } \\
\text { possibly Lens culinaris }\end{array}$ & $?$ \\
\hline $\begin{array}{l}\text { Neopalatial } \\
\text { Myrtos-Pyrgos }\end{array}$ & $\begin{array}{l}\text { Cadogan 1978; } \\
\text { Livarda in prep. a }\end{array}$ & $\begin{array}{l}\text { Vicia ervilia; } \\
\text { Hordeum vulgare hulled }\end{array}$ & no \\
\hline $\begin{array}{l}\text { Sissi } \\
\text { Ourania }\end{array}$ & $\begin{array}{l}\text { Livarda in prep. b } \\
\text { Sarpaki } 2009 b\end{array}$ & $\begin{array}{l}\text { Lathyrus cicera/sativus } \\
\text { Hordeum vulgare hulled } \square \text { - } \\
\text { row; Hordeum vulgare } \\
\text { hulled; } \\
\text { Lens culinaris }\end{array}$ & $\begin{array}{l}? \\
\text { Triticum } \\
\text { aestivocompactum; } \\
\text { Vicia faba }\end{array}$ \\
\hline $\begin{array}{l}\text { Final Palatial } \\
\text { Unexplored Mansion }\end{array}$ & Jones 1984 & $\begin{array}{l}\text { Hordeum vulgare hulled; } \\
\text { Lathyrus cf. ochrus; } \\
\text { Lathyrus sativus, Vicia faba }\end{array}$ & $\begin{array}{l}\text { Triticum dicoccum; } \\
\text { Triticum aestivum/ } \\
\text { durum }\end{array}$ \\
\hline $\begin{array}{l}\text { Postpalatial } \\
\text { Sissi }\end{array}$ & Livarda in prep. $b$ & Lathyrus cicera/sativus & $?$ \\
\hline $\begin{array}{l}\text { Pre/Protopalatial } \\
\text { Chamalevri }\end{array}$ & Sarpaki 1999 & possibly Olea europaea & $\begin{array}{l}\text { possibly Olea } \\
\text { europaea }\end{array}$ \\
\hline $\begin{array}{l}\text { Neopalatial/onwards } \\
\text { Kastelli Chania }\end{array}$ & Sarpaki forthcoming & $\begin{array}{l}\text { Hordeum vulgare hulled; } \\
\text { Lathyrus cicera/sativus }\end{array}$ & $\begin{array}{l}\text { Hordeum vulgare } \\
\text { hulled; } \\
\text { Lathyrus cicera/ } \\
\text { sativus; } \\
\text { Vicia faba minor }\end{array}$ \\
\hline $\begin{array}{l}\text { Kommos (Final/ } \\
\text { Postpalatial) }\end{array}$ & Shay and Shay 1995 & Thymalaea sp. & no \\
\hline Palaikastro & Sarpaki 1989 & $?$ & Vicia faba \\
\hline
\end{tabular}

wheats, and thus it is very well suited for extensive agricultural regimes. Easier bulk processing also allows clean grain bulk storage for immediate consumption and transport for distribution.

Regarding barley, unlike the hulled variety, the naked one has not been encountered at all after the Early Neolithic, although new preliminary data from Middle Minoan Smari in central Crete include another possible occurrence (Margaritis pers. comm.). Also, contrary to Hansen (1988, 44), the current dataset shows that 2-row barley did not replace, at least fully, the 2 -row variety by the beginning of the Bronze Age in the Aegean. At the Early Minoan I/Early Minoan II metallurgical workshop at Chrysokamino, rachis fragments of 2-row barley were positively identified from casts taken from furnace chimney fragments, and interpreted as part of threshing 

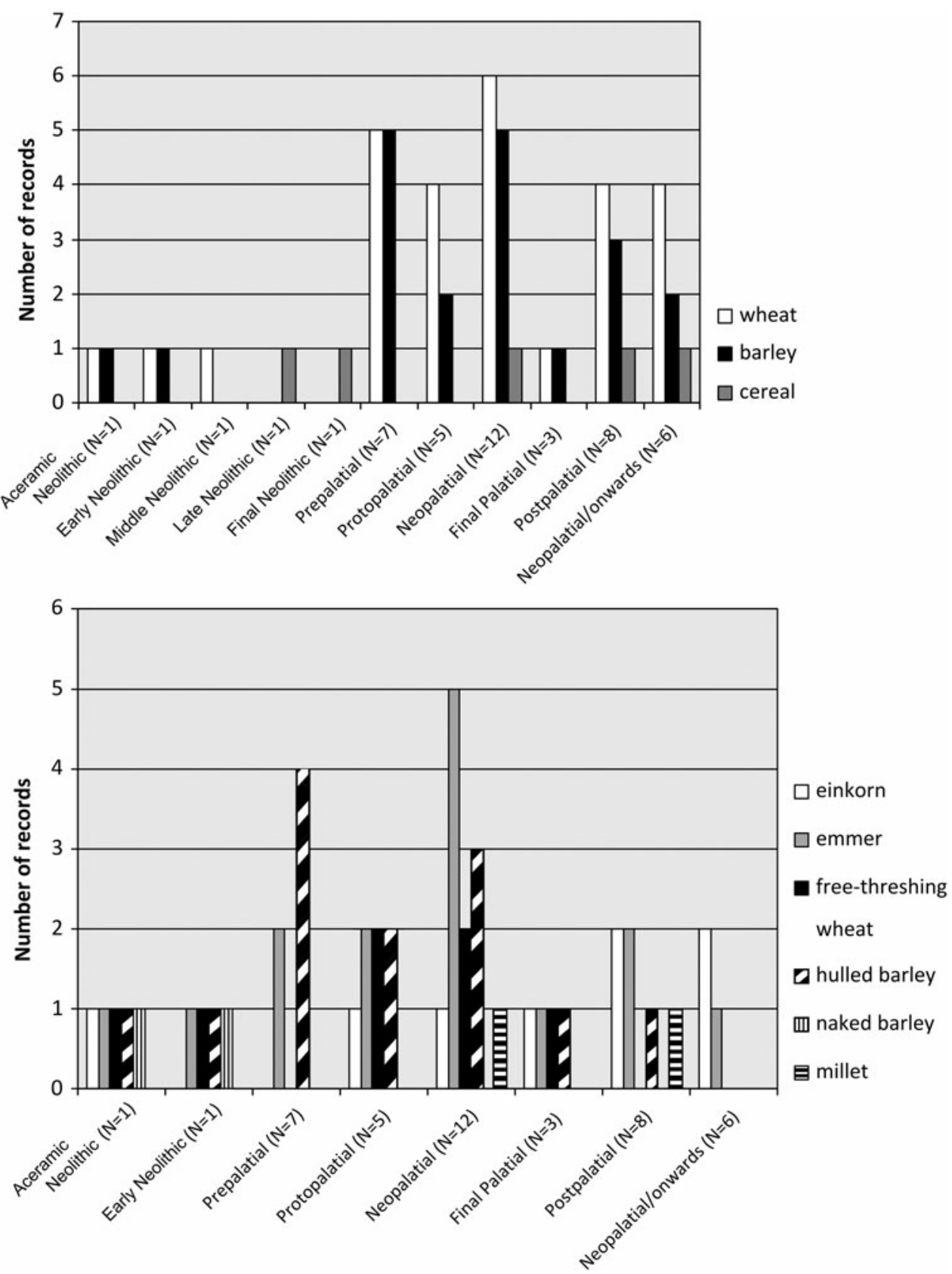

Fig. 6. The number of records of individual cereals in each period $(\mathrm{N}=$ the number of all records in a given period).

material used as temper for the chimney construction (Jones and Schofield 2006). No other secure evidence for the presence of 2-row barley exists but this cannot be taken as suggestive of its absence/ replacement. Its identification is based on the rachis and the grains, which all have a straight form as opposed to the 6-row variety that includes a larger proportion of twisted grains in addition to the straight ones. The presence, therefore, of straight grains alone cannot indicate the barley type. Straight barley grains are dominant in some samples of the Late Minoan II Unexplored Mansion storeroom, which allow hypothesising possible inclusion of two-row barley among the crops (Jones 1984, 303) even in this later period.

Hulled barley, emmer and free-threshing wheat are the only cereals that have been found as deliberately cultivated crops. Einkorn is present, and in fact in more records than free-threshing 
wheat, but always in low numbers and therefore its status as a commensal or a separate crop remains unclear. Valamoti $(2004,111-15 ; 2009,50-1)$, in her study of archaeobotanical material from northern Greece, noted its predominance in both the Neolithic and Bronze Age periods, with parallels in the Balkans, which contrasts with the emphasis on emmer elsewhere in Europe and many sites in the Near East. As environmental parameters cannot fully explain this pattern, Valamoti suggested that its dominance might be connected to culturally dictated dietary preferences, linked to the identity and/or origins/contacts of the populations inhabiting the area. Similarly, the prevalence of einkorn in Neolithic Toumba Balomenou, Chaeronia, in central Greece, in conjunction with other archaeological evidence, was interpreted as possibly some form of cultural traditionalism (Sarpaki 1995). In the case of Crete, the data are still too few to help discern associations and cultural links with other areas in the Aegean and beyond, allowing only some thick brush strokes, which suggest possibly greater emphasis on free-threshing wheat and emmer. Indeed the early presence of free-threshing wheat at Knossos within a few hundred years of its first recording as a stored product at mid-Neolithic Çatalhöyük (Bogaard et al. in press), and before its first appearance on current evidence in Cyprus (Sarpaki 2012a, 38), may provide some first indications of early contacts/networks with the East.

Regarding other cereals, two possible grains of spelt were recorded at Neopalatial Aghia Triada (Follieri 1985) but, in the absence of chaff to verify this identification, this evidence needs to remain tentative. More interesting is the case of millet, which appears for the first time in the Neopalatial period. Millet was found at the high-altitude 'villa' at Zominthos (Livarda and Kotzamani forthcoming) and a speculative cf. Panicum sp. record is reported from the Postpalatial strata of Quartier $\mathrm{Nu}$ at Malia (Sarpaki 2007). In both cases only a few seeds were recovered. Radiocarbon dating is scheduled for the common millet from Zominthos to confirm (or not) its dating to the Late Minoan IA period. Preliminary new results from Kastelli Chania also indicate the occurrence of a few more millet seeds (Sarpaki pers. comm.). Notably, there is a reference to millet from the storerooms of the palace at Knossos by A. Evans, accompanied by a sketch resembling its seed, although whether these grains have been kept to allow their re-examination, and, if so, their location, remain unknown. In particular, A. Evans $(1935,622)$ mentions that the only good evidence of grain storage inside the Palace came from the narrow area north of the 'Loom-weight Basement' in the East part with a Middle Minoan III filling. There, a deposit of burnt 'millet' grains was discovered, deriving probably from some upper storeroom of the Palace. These data, if indeed secure, alter the current archaeobotanical picture, according to which millet is found only in Bronze Age northern Greece (Vickery 1936; Valamoti 2009). Anticipating the radiocarbon data, it seems possible that by the Neopalatial period trade links may have contributed to the introduction of yet another cereal. This seems to have reached the Mediterranean from the north or the north-east, being most commonly found in Bronze Age central Europe (Zohary and Hopf 2000, 83-6), perhaps suggesting certain connection patterns for at least some parts of the island.

No significant spatial clusters of cereals can be observed to indicate local differences in their use. Free-threshing wheat is not present in western Crete but this is also the area with fewer archaeobotanical studies (Fig. 2). Likewise the social distribution of cereals does not reveal any significant patterning. Notably, none has been recovered from burials and sanctuaries (Fig. 7 ), but only spot find records are available from these contexts.

\section{Legumes}

Legumes are as common as cereals and formed an important component of the diet and agricultural economy of prehistoric Crete (Fig. 8). Their diversity is impressive (Fig. 9), and several of them were definitely grown as separate crops (range of species listed in Table $2^{5}$, and several spot find records). Lentils have the most regular occurrence and were found in substantial amounts in various contexts (Table 2), which seems to accord with the general picture

\footnotetext{
5 But note that large quantities of lentils have been found so far only in mixed samples, although the data from Monastiraki are not conclusive.
} 
Prepalatial

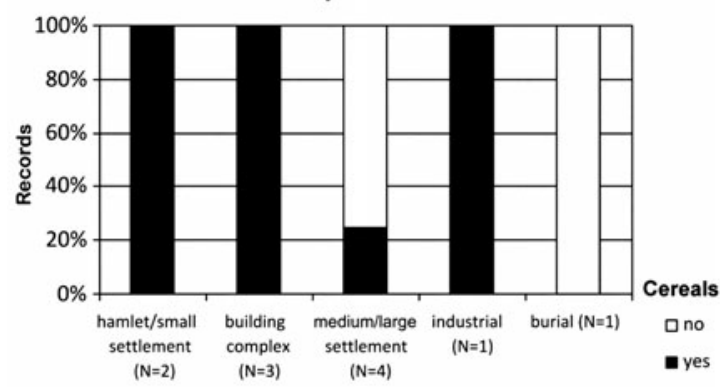

Neopalatial

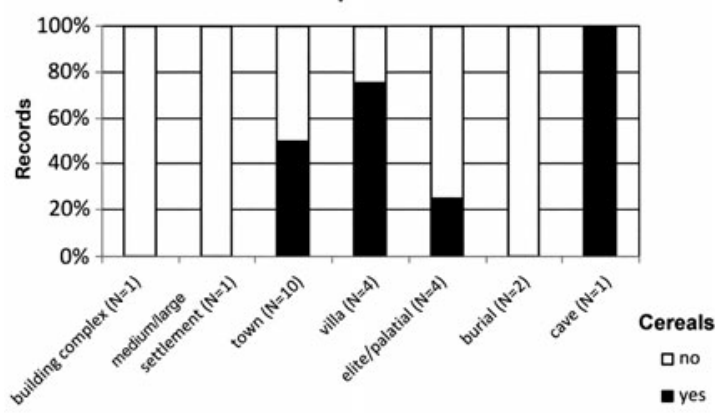

Postpalatial

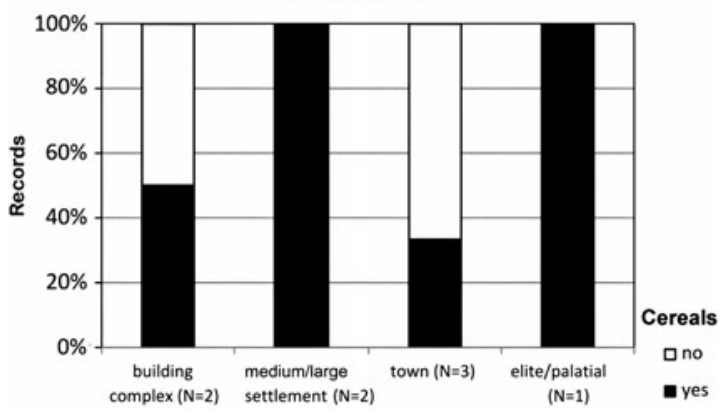

Protopalatial

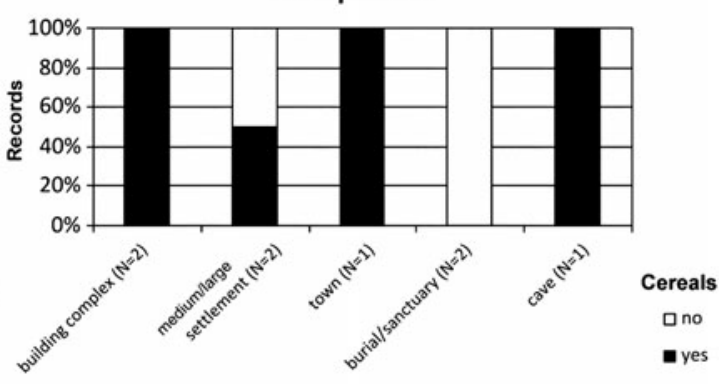

Final Palatial

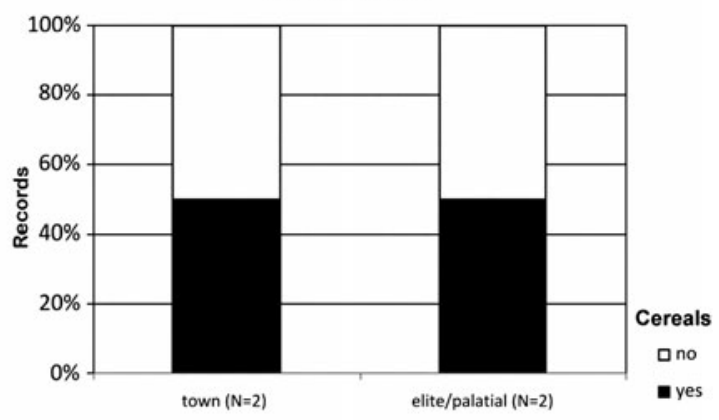

Neopalatial/onwards

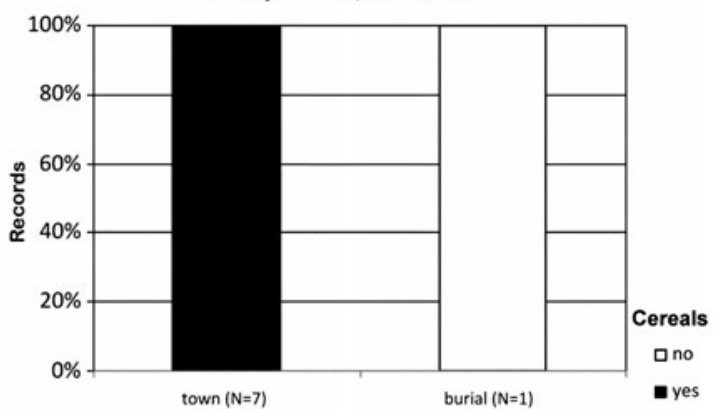

Fig. 7. The percentage of cereal records across different site types in each Bronze Age phase $(\mathrm{N}=$ the number of all records in a given site type).

for the whole of prehistoric Greece (Valamoti 2009, 71). Interesting is the case of the broad bean, tentatively identified initially in the Early Neolithic. If this identification is correct then it represents its earliest occurrence in Greece so far (compare with Megaloudi 2006, 56; Valamoti 2009, 73).

Spanish vetchling (Lathyrus clymenum) and Cyprus vetch (Lathyrus ochrus) are first found in the Prepalatial $^{6}$ and the Protopalatial ${ }^{7}$ period respectively (Fig. 9), and the latter is present in substantial quantities at the Unexplored Mansion, Knossos (Jones 1984). Remarkably, Cyprus vetch has not been found in any other Greek prehistoric archaeological context outside Crete, while the only other finding of Spanish vetchling comes from Late Bronze Age Akrotiri, Santorini (Sarpaki and Jones 1990; Sarpaki 1992a). Its occurrence at Akrotiri is perhaps no coincidence and it may be another testimony to the tight links between the two islands during this period. The incorporation of these two species in Cretan diet may thus be evidence of local or southern Aegean culinary traditions, and further investigation of their ecology, origins

6 Lathyrus cf. clymenum in Priniatikos Pyrgos (Molloy et al. forthcoming).

7 In Monastiraki (Sarpaki and Kanta 2011). 


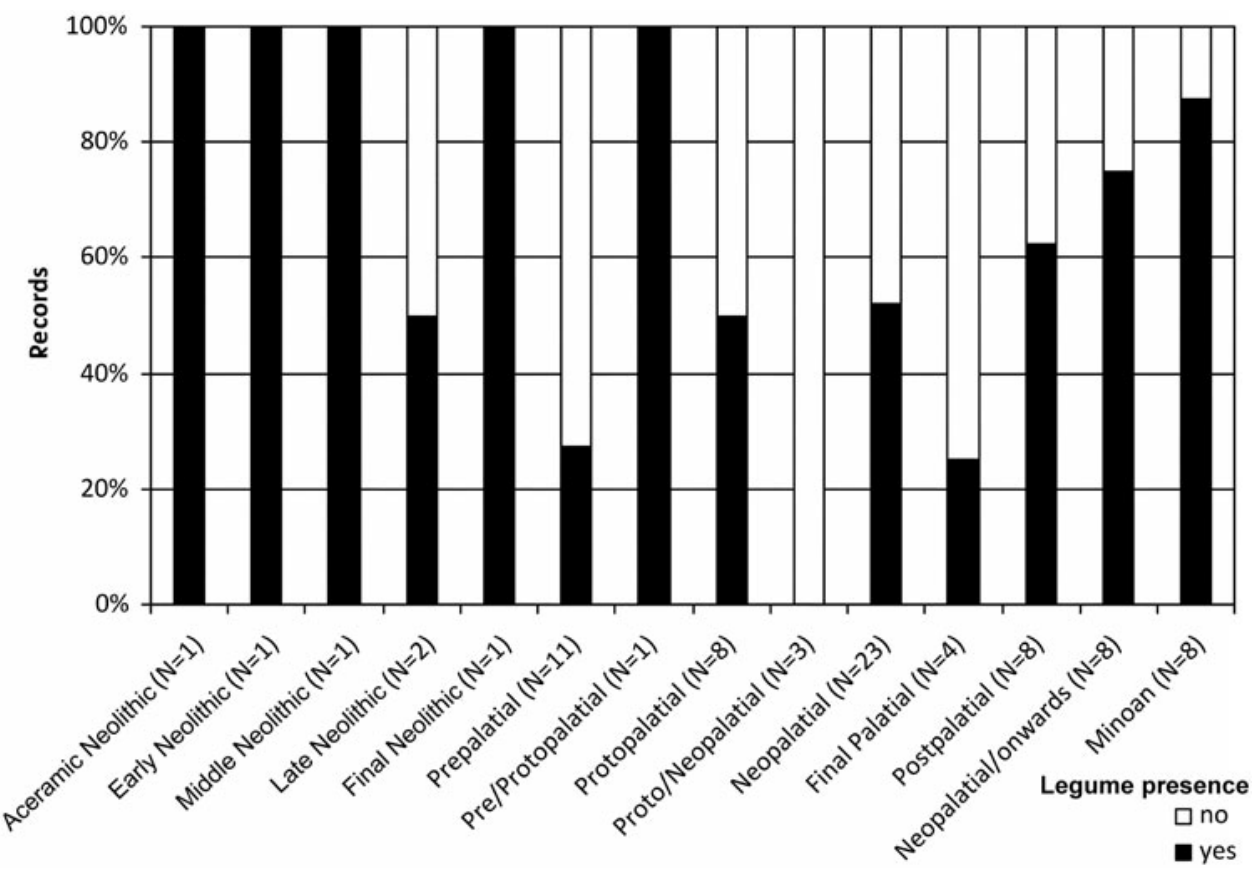

Fig. 8. The percentage of legume records in each period $(\mathrm{N}=$ the number of all records in a given period).

and use holds great potential to unveil aspects of Minoan social organisation and links and illuminate parts of the Minoanisation process as observed during the Neopalatial period.

The social distribution of legumes in the Bronze Age highlights their presence in all site types except in burials and sanctuaries (similarly to cereals) and the one Prepalatial industrial site (Fig. 10). What is significant here is the presence of legumes in both non-elite and elite contexts, including palatial sites contrary to previous claims (cf. Valamoti 2009, 76). In fact, no significant patterning is attested in terms of individual species and site types. Previous research has highlighted the importance of legumes in the Aegean diet and agriculture (e.g. Sarpaki 1992b; Hansen 2000) and their conspicuous absence from the Linear B palatial records (e.g. Halstead 1992). In comparison with the rather contentious role of legumes in elite contexts, the foregoing analysis from Crete demonstrates the incorporation and use of this type of food plant across the social spectrum.

\section{Fruits/nuts and condiments}

Fruits and nuts encompass a rather broad spectrum of taxa: acorn, almond, elderberry, fig, grape, Mediterranean hackberry, olive, pear, pomegranate and terebinth (Fig. 11; Fig. 12). Almond, fig, grape and olive seem to have had a regular presence since the Neolithic. The olives at Final Neolithic Kephala Petras are the earliest finds of this species, pushing back in time their first record according to the available evidence so far. No significant patterning is observed in terms of site types (Fig. 13). Remarkably, 60\% of the spot find records include this group of species, mainly in the form of olive stones, which is to be expected given their comparatively large size and easy identification with the naked eye. Herbs and condiments, although mentioned in Linear B records (Ventris and Chadwick 1973), are very rare, with only coriander being attested archaeobotanically (Fig. 12), but several wild species may account for this plant category. Generally, such species, often preferred for their softer parts, do not need to come into contact with fire for their processing or consumption, which means that they are rarely preserved in carbonised conditions. Research in the historic periods of northern Europe, where plant remains are commonly preserved in both carbonised and waterlogged conditions, indicates that there is a 


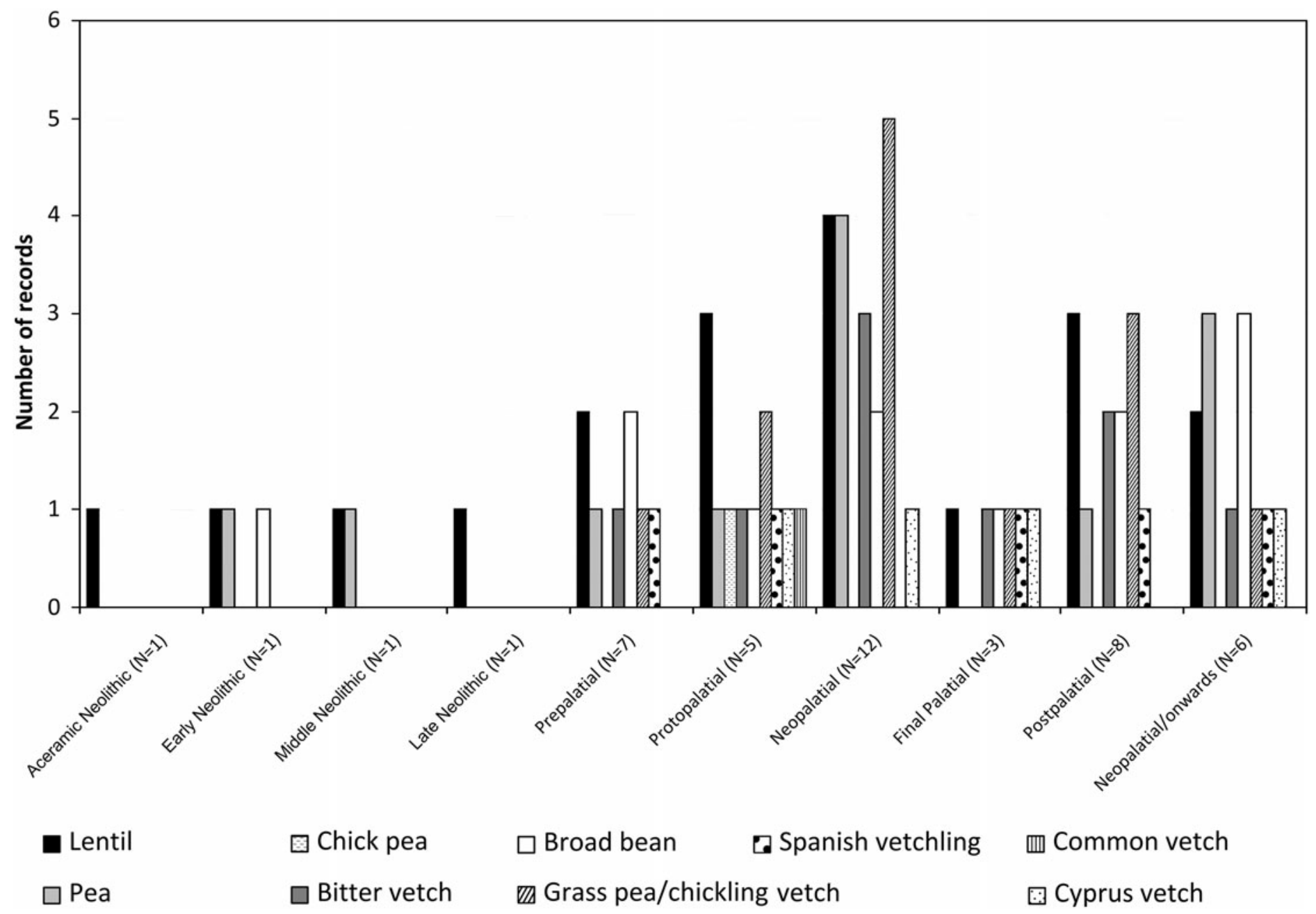

Fig. 9. The number of records of individual legumes in each period ( $\mathrm{N}=$ the number of all records in a given period). 

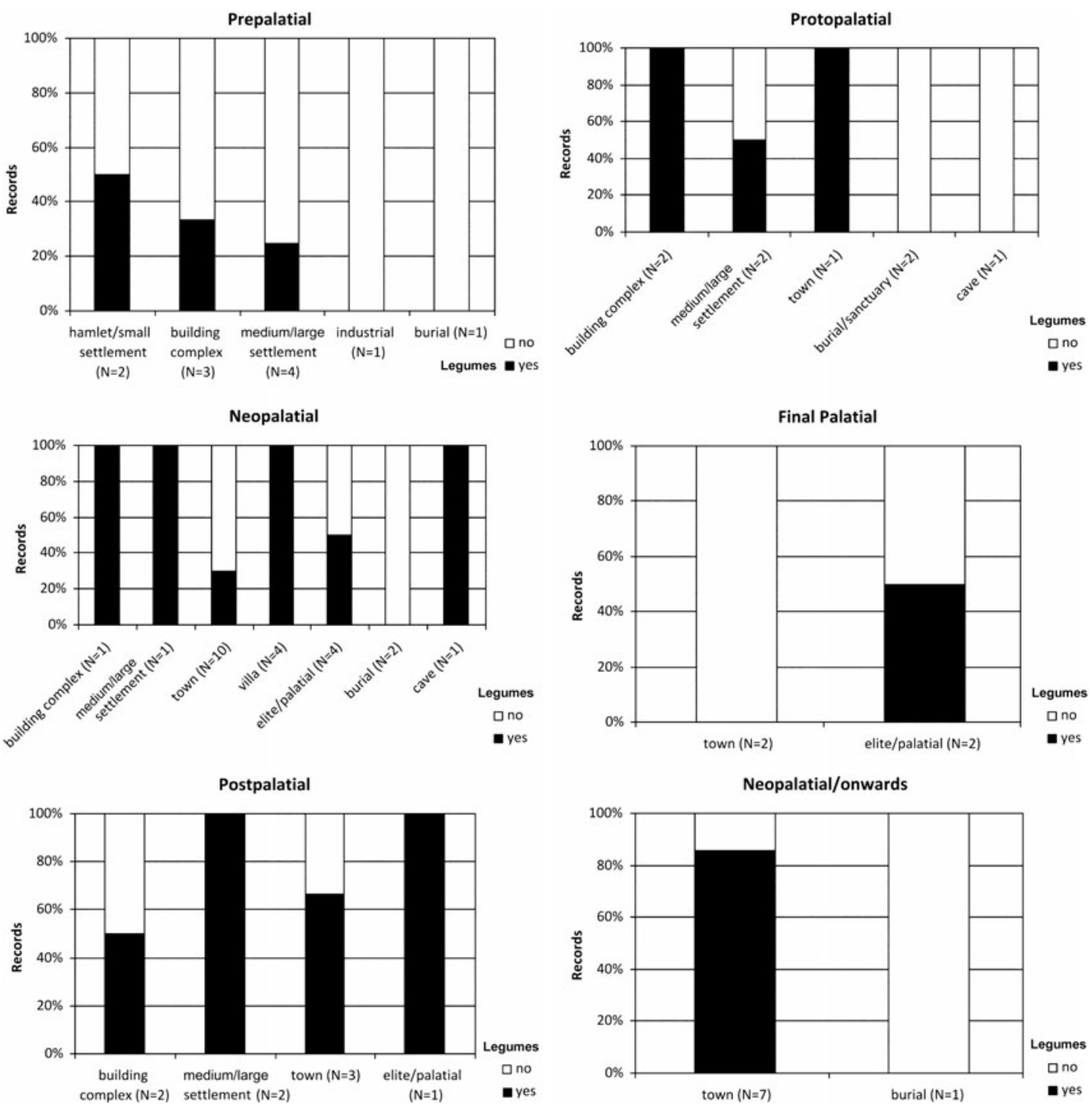

Fig. 10. The percentage of legume records across different site types in each Bronze Age phase $(\mathrm{N}=$ the number of all records in a given site type).

clear bias towards the preservation of most herbs and condiments in waterlogged environments (e.g. Livarda 2011). In the absence of such conditions in Crete the chances of their recovery are few.

Olive and grape have been the focus of much debate in Cretan archaeology, particularly in relation to the development of the palaces in the Bronze Age. In his 1972 seminal work on the 'Emergence of Civilisation' Colin Renfrew suggested that the systematic exploitation of vines and olives in the Aegean from the beginning of the Bronze Age resulted in local and regional agricultural specialisation that led to the need for a redistributive authority to ensure circulation of the various products which was eventually transformed into the authority of palatial institutions (A.C. Renfrew 1972). Several critiques and alternatives to this model have been suggested since (e.g. Halstead 1981; Halstead and O'Shea 1982; Gamble 1981). Attempts have also been made to use primary evidence to test the validity of the proposed models (e.g. Hansen 1988; Hamilakis 1996), concluding that systematic, intensive management of olive and grape for the production of oil and wine can be observed only in the second palace period (Late Minoan). Hamilakis (e.g. 1996; 1999) links their production fluctuations to power dynamics, that is, to elite competitive consumption of wine and use of perfumed oils in feasting contexts during the Neopalatial period and later to a more exclusive elite consumption, possibly in ceremonial practices. 


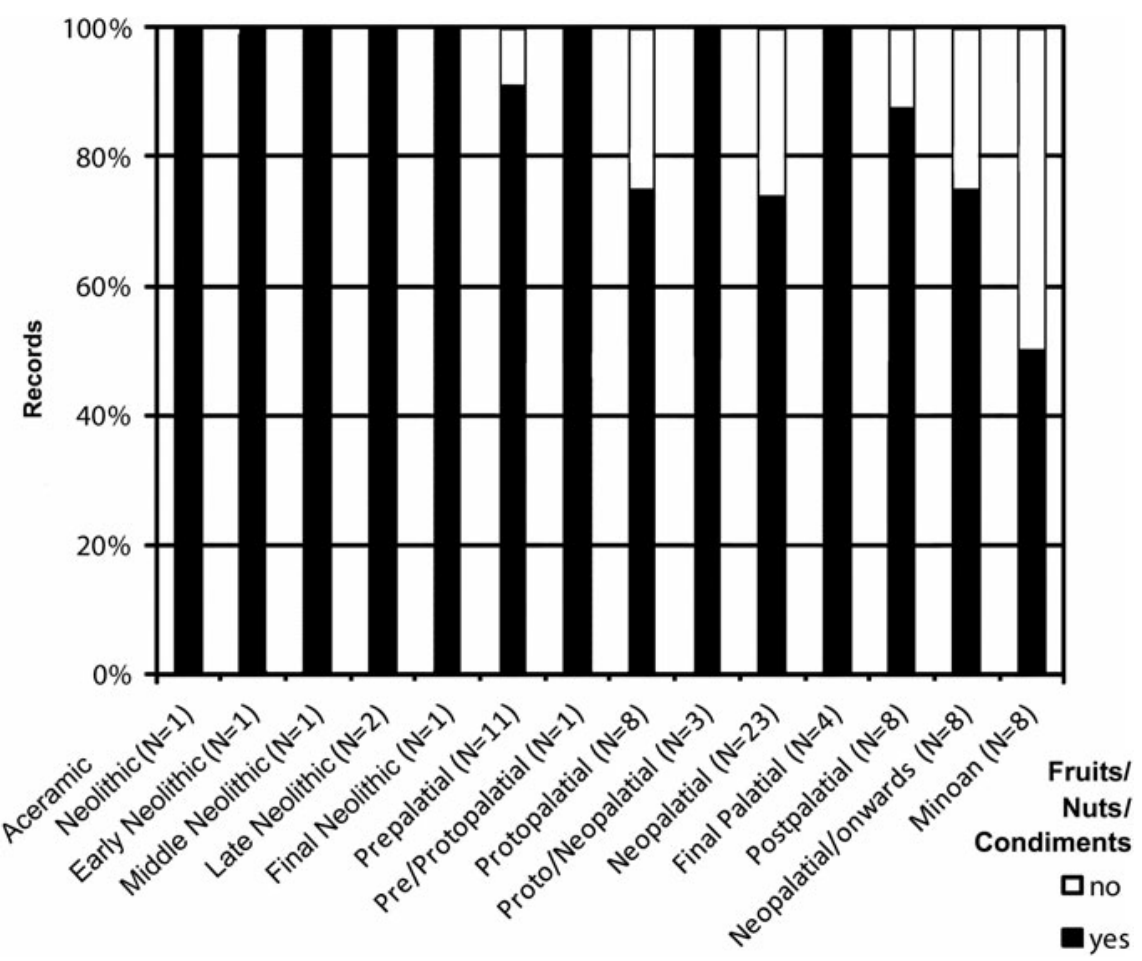

Fig. 11. The percentage of fruit/nut/condiment records in each period $(\mathrm{N}=$ the number of all records in a given period).

Wild olive and grape are present in Crete (Zohary and Hopf 2000, 146, 154) but currently there is no refined methodology to unequivocally distinguish these from their domesticated forms despite several inspired attempts (e.g. Mangafa and Kotsakis 1996; Terral et al. 2004). Genetic studies combining modern and ancient DNA hold, however, great potential to clarify these issues (e.g. Schlumbaum, Tensen and Jaenicke-Després 2008) and contribute to debates on their management. The first archaeobotanical indications for more intensive use of olive come from Prepalatial Chamalevri, where the numerous charred olive stone fragments resembling predeposition breakage were interpreted as the crushed by-products of olive oil production, used as fuel (Sarpaki 1999). Alternative suggestions have been also put forward by Valamoti $(2009,88)$, who urges more experimental work on the effect of digestion by animals on breakage patterns. Regarding the exploitation of grape by-products, archaeobotanical support for the possible presence of must remnants exists at the Prepalatial Myrtos Fournou Korifi settlement (J.M. Renfrew 1972) and Protopalatial Monastiraki (Fiorentino and Solinas 2006; Sarpaki and Kanta 2011). Recently, Sarpaki (2012b), drawing on the extensive evidence of wine production at Monastiraki, the recorded installations for wine production in Crete and iconographic evidence, added some interesting dimensions to the debate. She aptly observed that the treading installations (lecanae) have a rather small size with just enough space for one person to tread at a time, with the implication that the amount produced would not be enough to support extensive demand. Sarpaki (2012b) went on to suggest that grapes would have been trodden at harvest in the open, near the vineyards, in which case only a small part of the dregs would be transported back to the settlements to be kept within the wine for preservation and colouring purposes, while the lecanae may have been used only for a second pressing. Her argument is thus that wine production may have been a more widespread and earlier phenomenon than previously thought, but because of its nature it does not leave substantial archaeological traces. Other evidence (e.g. palynology, residue analysis), indicating intensive viticulture and oleiculture for the production of wine and olive oil respectively, remains open to debate (e.g. Sarpaki 2012a). 


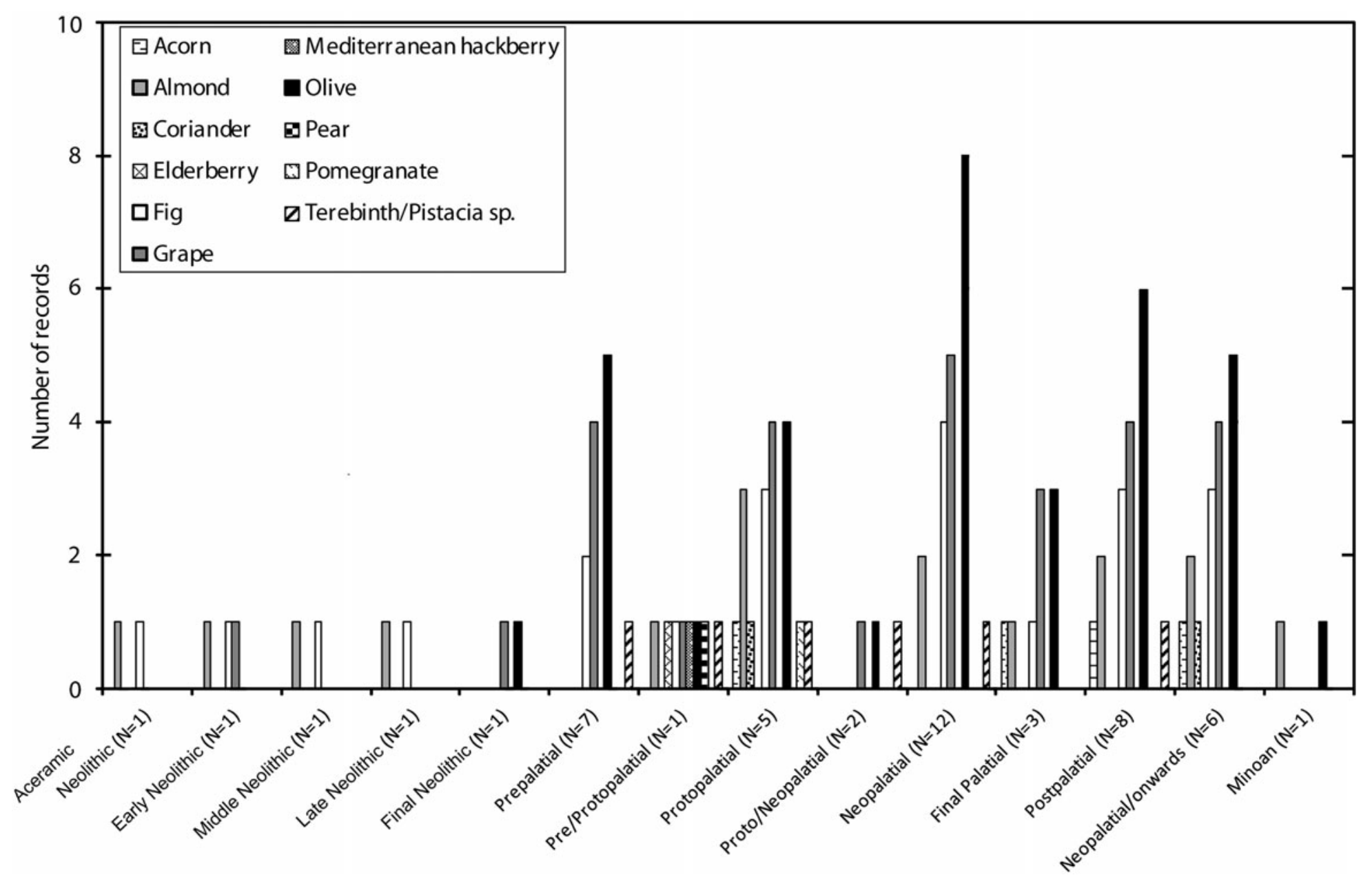

Fig. 12. The number of records of individual fruits, nuts and condiments in each period $(\mathrm{N}=$ the number of all records in a given period). 

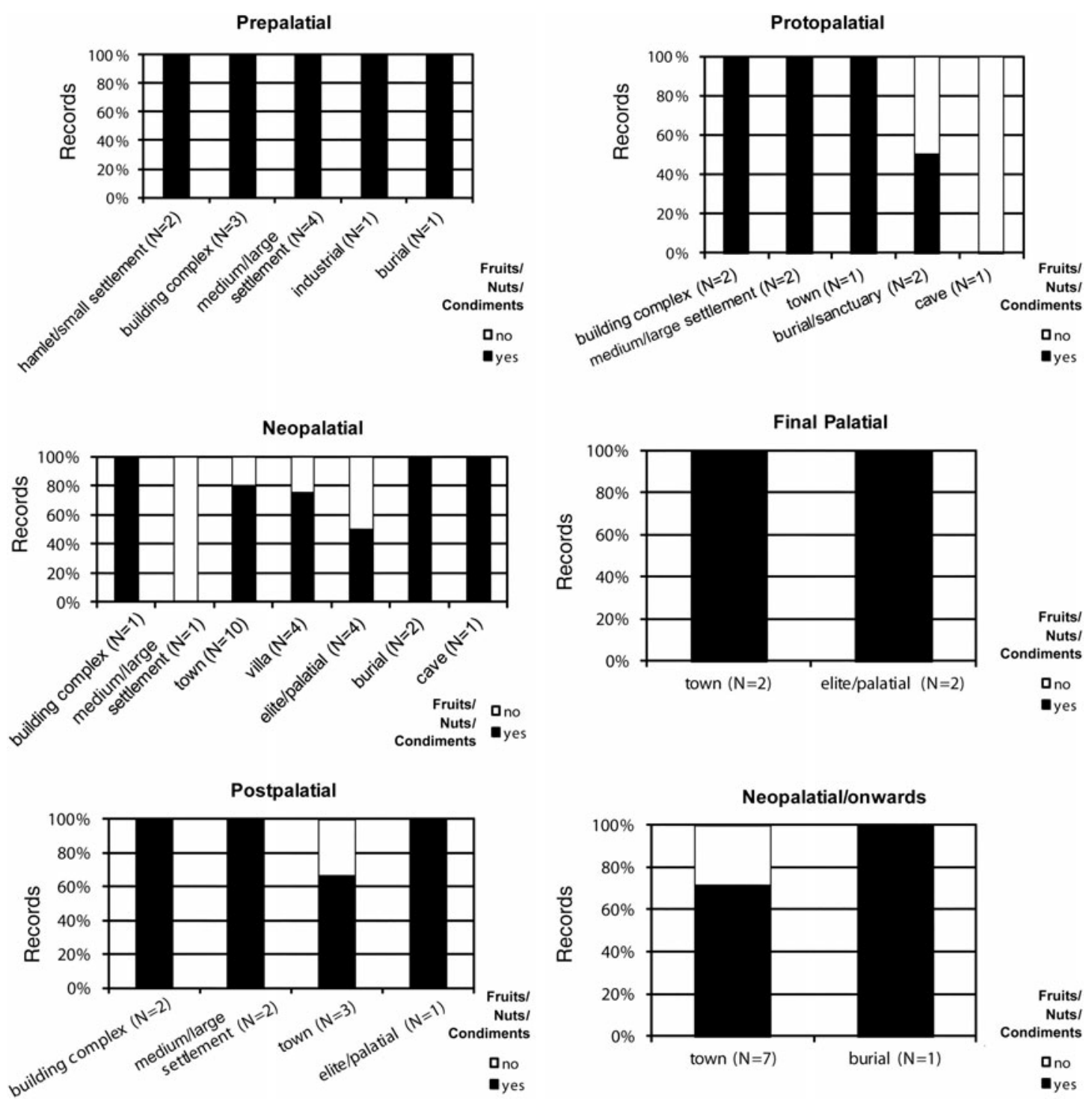

Fig. 13. The percentage of fruit/nut/condiment records across different site types in each Bronze Age phase ( $\mathrm{N}=$ the number of all records in a given site type).

\section{Other wild taxa}

Several wild plants have been identified in Crete, which would have either accompanied the harvested crops as weeds of cultivation and can be used to investigate aspects of agricultural practices, or been part of the surrounding vegetation. In the latter case their presence in archaeobotanical assemblages represents either accidental intrusions or deliberately collected items for miscellaneous uses, such as in diet, healing, handicraft, construction, heating and cooking, allowing insights into past life and social perceptions. Ethnobotanical sources (Fernald and Kinsey 1986; Gennadios 1914; Kavvadas 1956-64; Leporatti and Impieri 2007; Schmidt and Stavisky 1983; Skoula et al. 2010; Sturtevant 1952; Usher 1974; Uphof 1968) indicate the main potential uses of the wild taxa found in the archaeobotanical dataset (Table 3). Crete has a very rich tradition of wild plant gathering, and thus critical use of ethnobotanical information can contribute significantly to our understanding of analogous activities in the past.

Wild species are conspicuously absent from spot find records, but are present in almost $72 \%$ of the archaeobotanical studies, which is largely due to the use (or not) of small-aperture sieves. The 
Table 3. Potential uses of selected wild flora taxa present in archaeobotanical assemblages of the Cretan Neolithic and Bronze Age, as recorded in various ethnobotanical sources.

\begin{tabular}{|c|c|c|c|c|c|c|c|}
\hline Species & Dietary & Medicinal & $\begin{array}{l}\text { Animal } \\
\text { feed }\end{array}$ & $\begin{array}{l}\text { Handicraft/ } \\
\text { construction }\end{array}$ & $\begin{array}{l}\text { Aromatic/ } \\
\text { cosmetic }\end{array}$ & Dyeing & $\begin{array}{c}\text { Energy } \\
\text { production }\end{array}$ \\
\hline Adonis sp. & & $\mathrm{x}$ & & & & & \\
\hline Arundo sp. & & $\mathrm{x}$ & $\mathrm{x}$ & $\mathrm{x}$ & & & \\
\hline Asphodelus sp. & $\mathrm{x}$ & $\mathrm{x}$ & & & & & \\
\hline Atriplex sp. & $\mathrm{x}$ & & & & & & \\
\hline Beta sp. & $\mathrm{x}$ & & $\mathrm{x}$ & & & & \\
\hline Bromus sp. & $\mathrm{x}$ & & $\mathrm{x}$ & & & & \\
\hline Buglossoides arvensis & $\mathrm{x}$ & & & & & & \\
\hline Capparis sp. & $\mathrm{x}$ & & & & & & \\
\hline Carex sp. & $\mathrm{x}$ & & & $\mathrm{x}$ & & & \\
\hline Chenopodium sp. & $\mathrm{x}$ & & & & & & \\
\hline Chrysanthemum sp. & $\mathrm{x}$ & $\mathrm{x}$ & & & & & \\
\hline Cucumis sp. & $\mathrm{x}$ & $\mathrm{x}$ & & & $\mathrm{x}$ & & \\
\hline Cynodon dactylon & & $\mathrm{x}$ & $\mathrm{x}$ & & & & \\
\hline Erodium sp. & $\mathrm{x}$ & & & & & & \\
\hline Euphorbia sp. & & & & & & & \\
\hline Fumaria sp. & & $\mathrm{x}$ & & & & $\mathrm{x}$ & \\
\hline Galium cf. aparine & $\mathrm{x}$ & & & & & & \\
\hline Glaucium sp. & & $\mathrm{x}$ & & & & & $\mathrm{x}$ \\
\hline $\begin{array}{l}\text { Juncus cf. } \\
\text { heldreichianus }\end{array}$ & & & & $\mathrm{x}$ & & & \\
\hline Juncus sp. & & & & $\mathrm{x}$ & & & \\
\hline Linum usitatissimum & $\mathrm{x}$ & & & $\mathrm{x}$ & & & $\mathrm{x}$ \\
\hline Linum sp. & $\mathrm{x}$ & & & $\mathrm{x}$ & & & $\mathrm{x}$ \\
\hline Lolium sp. & & $\mathrm{x}$ & $\mathrm{x}$ & & & & \\
\hline Malva sp. & $\mathrm{x}$ & $\mathrm{x}$ & & & & & \\
\hline Medicago sp. & $\mathrm{x}$ & $\mathrm{x}$ & $\mathrm{x}$ & & $\mathrm{x}$ & $\mathrm{x}$ & \\
\hline Melilotus sp. & $\mathrm{x}$ & $\mathrm{x}$ & $\mathrm{x}$ & & $\mathrm{x}$ & & \\
\hline Onobrychis sp. & & & $\mathrm{x}$ & & & & \\
\hline Papaver sp. & $\mathrm{x}$ & $\mathrm{x}$ & & & & & \\
\hline Phalaris sp. & $\mathrm{x}$ & & $\mathrm{x}$ & & & & \\
\hline Plantago sp. & $\mathrm{x}$ & $\mathrm{x}$ & $\mathrm{x}$ & & & & \\
\hline Poa sp. & & & $\mathrm{x}$ & $\mathrm{x}$ & & & \\
\hline Polygonum sp. & $\mathrm{x}$ & $\mathrm{x}$ & & & & $\mathrm{x}$ & \\
\hline Portulaca oleracea & $\mathrm{x}$ & $\mathrm{x}$ & & & & & \\
\hline Primula sp. & & $\mathrm{x}$ & & & & & \\
\hline Raphanus raphanistrum & $\mathrm{x}$ & & & & & & \\
\hline Rumex sp. & $\mathrm{x}$ & & & & & $\mathrm{x}$ & \\
\hline Salix sp. & $\mathrm{x}$ & & & $\mathrm{x}$ & & & \\
\hline Sanguisorba sp. & $\mathrm{x}$ & $\mathrm{x}$ & $\mathrm{x}$ & & & & \\
\hline Satureja thymbra & & & & & $\mathrm{x}$ & & \\
\hline Setaria sp. & $\mathrm{x}$ & & $\mathrm{x}$ & & & & \\
\hline Sherardia arvensis & & & $\mathrm{x}$ & & & & \\
\hline Silene sp. & $\mathrm{x}$ & $\mathrm{x}$ & & & & & \\
\hline Spergularia sp. & & $\mathrm{x}$ & & & & & \\
\hline Thymelaea hirsuta & & $\mathrm{x}$ & & $\mathrm{x}$ & & & $\mathrm{x}$ \\
\hline Thymelaea sp. & & $\mathrm{x}$ & & $\mathrm{x}$ & & $\mathrm{x}$ & $\mathrm{x}$ \\
\hline Thymus sp. & & $\mathrm{x}$ & $\mathrm{x}$ & & $\mathrm{x}$ & & $\mathrm{x}$ \\
\hline Trifolium sp. & $\mathrm{x}$ & $\mathrm{x}$ & $\mathrm{x}$ & & & $\mathrm{x}$ & \\
\hline Trigonella sp. & $\mathrm{x}$ & $\mathrm{x}$ & $\mathrm{x}$ & & $\mathrm{x}$ & & \\
\hline $\begin{array}{c}\text { Valerianella cf. } \\
\text { microcarpa }\end{array}$ & $\mathrm{x}$ & & & & & & \\
\hline Verbascum sp. & & $\mathrm{x}$ & & & & & \\
\hline Verbena sp. & & $\mathrm{x}$ & & & & & \\
\hline
\end{tabular}




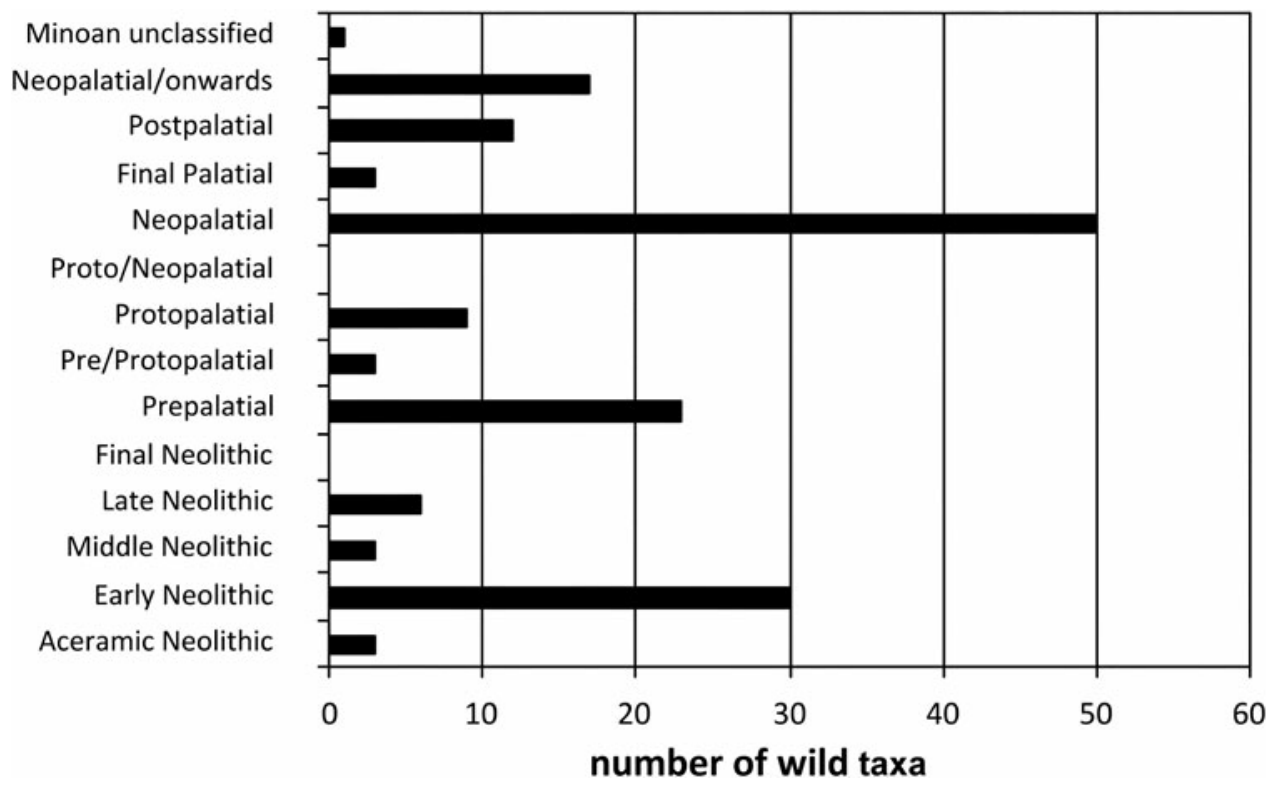

Fig. 14. The number of wild taxa in each period.

available data indicate that the widest range of wild plant taxa is observed in the Neopalatial records (Fig. 14). Periods that lack any substantial information regarding wild flora are, however, represented either by a handful of soil samples of limited volume or by chance finds. The relatively broad spectrum of wild flora attested in the Early Neolithic assemblages from Knossos (Sarpaki 2009a) adds valuable new information to this largely unknown early period. Although there is no direct evidence on the selective use for most of these species, their presence may imply some continuation of gathering activities that would complement the benefits of agricultural production.

The quantities of wild species per sample across all records are generally low. Only three out of the 83 wild taxa have a presence of 50 or more individuals in a single record: Malva sp. (Aceramic Neolithic Knossos), Poaceae (Neopalatial Ourania) and Thymelaea sp. (Final Palatial/Postpalatial Kommos). Of these, Thymelaea seems to be a largely pure assemblage, which increases the possibility of its deliberate collection. Additionally, wild radish (Raphanus raphanistrum) pod fragments are present in relatively large amounts in Early Neolithic I and Early Neolithic II levels of Knossos, which Sarpaki (2009a, 224) interprets as a probable sign of its deliberate use. No particular associations between specific species and site types are discerned.

The presence of flax (Linum usitatissimum/Linum sp.) merits further attention. Flax is a valuable oil and fibre source, used in diet, lighting and weaving of clothes, ropes, textiles and nets. Its wild progenitor $(\mathrm{L}$. usitatissimum ssp. bienne $=\mathrm{L}$. bienne) has a wide distribution, including the Mediterranean basin and Crete (Zohary and Hopf 2000, 129). Sarpaki supports its early cultivation in Crete, based on the morphometric characteristics of two seeds more than $3.5 \mathrm{~mm}$ in length found in the Early Neolithic I levels of Knossos, which correspond to the size range of the cultivated species (lower limit at $3 \mathrm{~mm}$ ). While reliance on morphometric evidence to directly identify domestication and cultivation can be precarious (Jones and Brown 2007), particularly when based on low specimen numbers, the regular presence of flax ${ }^{8}$ in prehistoric sites in Crete may indeed reflect its intentional use, even in its wild form.

A significant problem related to the study of wild taxa is that their identification is not always detailed enough to reach the species level due to either their poor preservation or the analytical abilities of each researcher and/or his/her access to reference collections and identification

8 Note also the new evidence for the presence of flax from Late Bronze Age contexts at the site of Papadiokambos, East Crete (Margaritis, pers. com.) 
manuals. Without this level of identification, however, no sufficient information can be gathered on the uses and the ecology of these plants, which are necessary to infer past agricultural practices and allow in-depth interpretations. Considering also their low overall numbers, no systematic study has been published so far using wild species for the reconstruction of past agronomic management practices in Crete.

\section{A RESEARCH AGENDA FOR PREHISTORIC CRETE}

\section{Methodological recommendations}

Since the beginning of the 1990s better archaeobotanical control on sampling has become the norm. Despite, however, the numerous projects underway in Crete only a few have invested resources for the recovery of plant remains.

Adoption of rigorous methodologies can help improve the data quality, and thus establish archaeobotany as an important component of archaeological research. The first step is consultation of archaeobotanists before an excavation begins in order to design sampling strategies according to the research questions of each project. We suggest that judgement sampling creates more problems than solutions, and that systematic sampling with continuous scanning, assessment and later sub-sampling of the material after, if not during, each field season is the way forward. The systematic collection and scanning of material from every single excavation unit of a site allows quick identification of areas of high and low activity and samples of particular interest. An initial assessment of the results can also contribute to their quick incorporation into archaeological interpretations, with the key being close collaboration and frequent exchange of information between all archaeologists. Proper integration of archaeobotanical/bio-archaeological work cannot be achieved unless the directors consider this workstation as another 'trench' where a workforce team needs to be allocated. Flotation and water-sieving, the standard methods for bio- archaeological material processing, are simple processes in which workmen and archaeologists can be very easily trained. So, rather than the archaeobotanists struggling to conduct the flotation themselves, a small team of people can be in charge of this task under the supervision of the archaeobotanists, who can in turn use their time efficiently to assess and study the processed samples, for which specialised knowledge is required. Treating flotation as an equal workstation to a trench in terms of resource and labour allocation can have a significant positive impact on the full integration of archaeobotanical results into contextual interpretations of the site and on the time needed for a quick completion and publication of the results. Such an approach will also render systematic sampling more feasible, with all the rewards that follow in terms of the quality of information gained. This will also result in an increased number of samples available and therefore in a better spatial coverage of sites. An adequate number of samples is dependent on the size of each excavation. As the excavation process is irreversible, it is very important to create a bank of the maximum potential information, of which a subsample can be processed/studied according to the availability of time, resources and the research questions posed, while the remaining samples can be stored for future study. Better communication between research institutions and the Ephorates on the availability of material may provide another avenue for their study. Based on our experience there are many willing archaeobotanists in search of material for research, including $\mathrm{PhD}$ projects, but access to assemblages is often restricted, largely due to lack of knowledge of the existence of material.

To maximise the potential for the recovery of statistically significant assemblages of plant remains, 40 to 60 litres of soil after dry-sieving need to be routinely collected from all contexts with dimensions large enough to contain this volume of soil. For contexts that cover extensive areas, multiple samples from various parts need to be collected to account for the spatial variability, which can be later amalgamated should this be deemed necessary by the archaeobotanist. Equally important is the use of sieves with apertures between 0.2 and $0.3 \mathrm{~mm}$ to ensure the recovery of small items. 
Publication of archaeobotanical studies and reporting quality is the next point of concern. In addition to any synthetic study, the raw data on a sample-by-sample basis need to be published, with full quantification of each item, rather than a mere mention of their presence. Without this detailed level of information, which would allow investigation of the variation within the dataset, no in-depth interpretations can be achieved. In the absence of any centralised body in Greece that acts as a depository and archive of archaeological/archaeobotanical reports, we took the initiative to build up a database with all the raw plant macro-remains data available from Crete, which we aim to continuously update, with plans to make it publicly available through the University of Nottingham (UK). Such a tool will be invaluable for the contextualisation of all future archaeobotanical studies in the island.

\section{Research priorities and new approaches}

Several interesting issues have been raised by the analysis so far. Primary data to inform on the plant resource base are still conspicuously absent from large parts of the island, highlighting the need for more archaeobotanical studies, particularly from the western part of Crete (prefectures of Chania and Rethymno). Regarding the temporal representation, the Neolithic is by far the most understudied. Nevertheless, more archaeobotanical information is needed from all periods, as even for the Neopalatial period - which has the highest number of records - thorough understanding of plant management is lacking. The site type classification has been only rough but the results are telling: tombs, cemeteries and sanctuaries are very rarely sampled for plant remains, leaving a conspicuous gap in the dataset when it comes to an understanding of the potential role and meaning of different plants in ritual practices and pursuits. Most higher-status sites, particularly palaces and villas, have been the focus of older excavations without archaeobotanical control, and therefore more data from such contexts will be a welcome addition that will allow meaningful comparisons with other contemporary small and large settlements, and will contribute towards a better understanding of the role of the elite in shaping social dynamics.

As the archaeology of Crete is rapidly changing, with new evidence for its habitation well before the Neolithic period (e.g. Kopaka and Matzanas 2009; Strasser et al. 2010), it is imperative to seize this opportunity and incorporate plant remains in the study of these earlier phases. Crete has a strategic location in relation to the spread of agriculture from western Asia and these early contacts of people and ideas may be traced in the emergence of agriculture and farming systems on the island. The early presence of free-threshing wheat and the investigation of its use and genetic make-up offer a promising avenue in this research direction. These studies can then provide the necessary time depth to understand the historical trajectories which led to the specific socioeconomic structures that shaped the Bronze Age across the island.

In the Bronze Age, crop diversification has been claimed as an important parameter in the emergence of palatial societies (e.g. A.C. Renfrew 1972; Halstead and O'Shea 1982). According to this study, the meagre data from the Neolithic period seem to suggest an already high diversity of both crops and wild plant resources. Similarly, all major cereals, legumes, fruits and nuts are present in the Prepalatial period. From the Protopalatial period onwards only a few more species are possibly added (e.g. chickpea in the Protopalatial and millet in the Neopalatial period). These new species have been recovered in low numbers and their status as new cultivated crops remains to be verified. This is yet another reason that justifies the need for more data collection also from later periods. When the wild resources and the numerous herbs, oilproducing plants and vegetables native to Crete that are rarely preserved by charring are added, it becomes evident that the available plant resource base would have been far more extensive. Increasing archaeobotanical evidence also shows that olive and grape were indisputably known and consumed in Crete since the early phases. Their consumption shows the same overall pattern. Their scattered remnants across sites of all periods in rather low quantities are consistent with their occasional use as a snack or a secondary meal component. In fact, the picture that gradually emerges is that, as more studies are conducted, more data on these fruits, as well as on other plant species, are added. Overall, the plant resource base, as attested by the 
evidence thus far, indicates a potentially large enough diversity in the diet and the use of plants across all periods to have also acted as a balancing mechanism in the management of resources, especially considering the variable success rates in crop production. Presence and knowledge, however, of a species do not necessarily suggest intensive exploitation with a view to specialisation of its products or by-products.

Halstead $(2004,194)$ cautions that social change may be reflected not in the changing importance of certain plant (and animal) species or of their management techniques, but in changes of their social context defined as 'changes in rights of consumption and obligations of production'. This has been mostly demonstrated for the later periods by comparisons between textual Linear B and bio-archaeological evidence from mainland Greece that indicate selective control of the palace over crop and livestock management (Halstead 2004). Drawing upon the synthesis of the available archaeobotanical evidence, several suggestions can be made towards a better understanding of these processes. In addition to the attested diversity of the available plant resources in all periods, no patterning has emerged associating certain species with particular areas. Furthermore, the data are not sufficient or their quality is not high enough to establish, or perhaps reject, associations between certain species and site types, but so far no restrictions on access to any plant resources at a broad social level are apparent. Olive may be the only species that stands out, as it is the sole plant found in all Bronze Age burials in the dataset, but notably its remains were recovered as spot finds. This leaves open the question as to how solid this association is, while more systematic retrieval of material is needed to assess its role in ritual practices.

A contextualised approach, taking into account the site type and the contexts of the plant samples, holds the potential to illuminate how the management of resources may be linked to social organisation and interdependence dynamics between social units within regions and between different regions, which can then be used to infer social meanings of consumption. For instance, a thorough investigation of the husbandry regime of glume wheats versus free-threshing cereals in each site type where these occur may provide some insights into potential differences in their management and possible employment for different purposes. Free-threshing wheat is a crop very well suited for extensive, bulk production and transport, and although present in various sites the only two where it was found stored were rather special, the Unexplored Mansion, Knossos (Jones 1984), which is a high-status context, and the cave at Ourania that seems to have operated as a well-organised, large-capacity storage station among other possible functions (Sarpaki 2009b; Kopaka 2009). Free-threshing wheat is also the only one of the wheat types available in prehistoric Crete that can be used to make raised bread and can thus be involved in different foodways.

The scale of production of different crops can be associated with different exchange/trade links and/or relations of social obligations. Archaeobotany nowadays is better equipped to tackle these issues and provide interesting research avenues. New research has demonstrated that sites rich in grain relate to large-scale activities (production and/or consumption), whereas sites with samples rich in chaff/weed are more indicative of small-scale, everyday processing activities (Van der Veen and Jones 2006). A better understanding of the scale of various activities in different sites can thus be gained, while investigation of grain-rich sites has the potential to further illuminate instances of crop specialisation. Examining archaeobotanical assemblages from different site types in this light can provide some first insights into the role of different social units in each time period. The grain-rich records for instance from Ourania cave (Sarpaki 2009b) and MyrtosPyrgos (Cadogan 1978; Livarda in prep. a) may provide some evidence for such larger-scale activities.

To examine the husbandry regimes involved in the production of crops, studies of wild species clearly defined as weeds in archaeobotanical assemblages are traditionally employed. The problem of the vast majority of archaeobotanical studies on prehistoric Crete so far is that the quality of the available data does not provide the required resolution to use this line of evidence. The normally low quantities of mixed material do not allow disentangling associations between crops and their weeds, while in stored assemblages the crop is usually well cleaned, and therefore weeds occur in too low quantities to provide meaningful results. 
In anticipation of better methodologies that will improve the data quality and of the completion of preliminary studies, new advances in archaeobotanical research allow revisiting old assemblages to obtain much-needed new data. Stored plant material can now be subjected to stable isotope analysis in order to understand husbandry regimes with important implications. Several assemblages of cereals and legumes have been identified (Table 2) that can lend themselves to such examination. In particular, modern experiments have demonstrated that the effect of animal manure application results in significantly raised $\delta^{15} \mathrm{~N}$ values in cereal grain and chaff, and clear correlations can be obtained between values and the intensity and longevity of cultivation with or without manuring (Bogaard et al. 2007; Fraser et al. 2011). Thus using only a handful of stored cereal grains can help us infer how closely integrated and intensive animal farming and agricultural production were, and contribute to insights into the stability of land tenure, as the effect of manuring on soil productivity builds gradually, implying long-term investment in arable land (Fraser et al. 2011, 2802). Pulses can also be used in a similar way, but due to their nitrogen-fixing qualities only intensive manuring is detectable (Fraser et al. 2011, 2802). Pulses, however, as well as cereals may also be subjected to the study of their carbon isotope discrimination $\left(\delta^{13} \mathrm{C}\right)$ signatures, which is useful for instance in the investigation of water availability and irrigation regimes (e.g. Ferrio et al. 2005). Recent work on carbon stable isotopes of stored cereals from the Bronze Age tell at Assiros in northern Greece has demonstrated the potential of this method to address issues such as mobilisation of resources, as the $\delta^{13} \mathrm{C}$ values seem to be consistent with pooling of local cereal harvests collected in one year (Heaton et al. 2009). The implications are that we might be witnessing either communal storage or mobilisation of grain by a central authority/elite, the latter being supported by the archaeology of the area (Heaton et al. 2009, 2232). The same study has provided support for the growing of emmer and spelt together in the same field, which allows insights into resource management. Close integration of traditional archaeobotanical work and stable isotope analysis with tight archaeological control and contextual data can now constitute another way forward to understand mobilisation of resources (e.g. provenance from different/same fields or areas, long/ short-term storage, etc.) before and after the emergence of palatial societies in Crete, starting with data that are already available. The case of Ourania cave may be a good starting point for an investigation of how and why harvests were pooled and stored in this context. Animal and human bone analysis can further tie in with such archaeobotanical and stable isotope studies to illuminate aspects of animal feeding regimes and human consumption patterns in a heuristic research line that will lead to more in-depth approaches to early social organisation and changes.

Some final thoughts on olive oil and wine, given their attributed importance in Minoan society, are offered, although an in-depth discussion on the beginnings and intensification of oleiculture and viticulture is outside the scope of this article. The relatively low archaeological visibility of grapes, olives and their processing by-products may be an artefact of sampling and taphonomic parameters. For instance, unless the crushed olive oil by-products are used as fuel or form part of a destruction level, they will not be preserved. A similar condition applies to winemaking residues, while for both plants the scenario of their post-harvest processing for oil and wine near the fields, which are areas outside the standard focus of archaeological excavation, is also a possibility. Equally, containers related to their production could have been made of perishable materials (e.g. wood, skin), not easily preserved and thus detected archaeologically.

Elaborating on wine, the implication that the increased production of drinking vessels, referring mainly to the plain conical cups, and of winemaking installations in the Neopalatial period is linked to increased wine consumption by the elite in feasting contexts for power negotiation (e.g. Hamilakis 1996; 1999) may benefit from some rethinking. We believe that a distinction first needs to be made between the production and consumption processes. Regarding drinking vessels, firm associations between these and exclusive use of wine cannot be maintained. Although wine, being hard to produce, may have been highly sought, without some ground- truth testing, for instance by residue analysis, this association is not straightforward; other alcoholic drinks may have been also/additionally employed, such as some form of beer from the widely available barley, but also (aromatic?) water in the quite arid environment of Crete may have been considered a valuable resource worthy of offering in certain ceremonies. Different 
drinks may also have been used as part of the same occasion by different people or at different stages. Younger and Rehak $(2008,154)$ suggest that the conical cup was adaptable to various other uses, such as being a container of small amounts of food or other miscellanea. Another question worth posing is whether the indications for the increase in the numbers of conical cups can signify social habits of more individualistic consumption versus more communal culinary foodways in earlier periods. This would then imply different drinking/eating manners but perhaps not necessarily drinking/eating more of one product. More evidence for increasingly different processing and consumption manners comes from Bronze Age elite contexts of the palatial period. Isaakidou (2007) has identified more intensive dismembering and filleting in the palatial period of Knossos, resulting in smaller meat parcels that could be cooked in new ways within the available cooking vessels of the period, and thus served as part of more diacritical and elaborate dining. In arguing the above we do not, however, negate a possible increased wine production in the Neopalatial period. Indeed, if the lecanae were used for a second pressing as suggested by Sarpaki (2012b), which may be linked to more wine extraction, this may add some support for its (and/or its by-products', e.g. vinegar as a preservative agent) increased demand. So, if we assume that the increased visibility of winemaking installations in the Neopalatial period is linked to increased, intensified wine production, then all social dynamics need to be investigated in parallel to suggestions for higher wine consumption within the palaces, including for instance increased demand as a result of trade networks in a period of extended cultural and administrative influence beyond Crete (e.g. Younger and Rehak 2008, 140; Knappett, Evans and Rivers 2011). Increased availability of wine may have further instigated a pursuit for new means of differentiation by the elite, such as for instance, better quality of wine. What we are suggesting here is that, in order to fully grasp the social dynamics of prehistoric Crete, we may need to embrace all the wide array of archaeobotanical, along with other archaeological and scientific, evidence in a contextualised, integrated and archaeologically informed manner in order to obtain fresh insights into social practices and displays. This way we will be able to gain more in-depth readings of the multiple systems operating within the economy of the Cretan societies in line with the new theoretical models of palatial societies (see e.g. Halstead 2011; Nakassis, Parkinson and Galaty 2011) as these are being built upon the increasing body of archaeological and textual data.

\section{CONCLUDING REMARKS}

Close examination of the existing archaeobotanical dataset has enabled the delineation of current research on Neolithic and Bronze Age plant use in Crete. Both methodological and theoretical issues have been addressed, lacunae have been identified and new research directions and approaches have been outlined. What emerges from the foregoing discussion is the paramount importance of a well thought-out and sound methodological basis for the recovery of plant remains, which in turn will permit their full integration into the archaeological discourse of social models, practices and meanings. Archaeobotany is also now better equipped with new tools and approaches, allowing revisiting and rethinking current assemblages. More importantly, however, it is now time to take advantage of proper integration of the actual primary data implicated in the theories of resource organisation and mobilisation to illuminate the threads that shaped social dynamics in prehistoric Crete.

\section{ACKNOWLEDGEMENTS}

We are very grateful to our colleagues Yannis Papadatos, who provided us with valuable information on the character and archaeology of prehistoric sites in Crete, Anaya Sarpaki for her constant support, generous sharing of information and useful comments on an earlier draft of 
this paper, and Hector A. Orengo, who patiently helped with the figures of the text. Thanks also go to Evi Margaritis for communicating to us some unpublished information. We would further like to warmly thank all those archaeologists who entrusted us with the study of the plant remains from excavations they directed, allowing us to better understand past life in this fascinating island: Gerald Cadogan, Jan Driessen, Eleni Hatzaki, Barbara Hayden, Barry Molloy, Diamantis Panagiotopoulos, Yannis Papadatos, Yannis Sakellarakis, Efi Sapouna-Sakellaraki and Metaxia Tsipopoulou. The Semple Fund of the University of Cincinnati generously assisted financially part of the study of the Knossos Little Palace North material and Psychas Foundation the study of the material from Zominthos. Our sincere thanks are finally due to Paul Halstead and Amy Bogaard for their useful comments on an earlier draft of this paper and to Sue Sherratt for her editorial input.

\section{Alexandra.Livarda@nottingham.ac.uk}

\section{REFERENCES}

Bogaard, A., Heaton, T.H.E., Poulton, P., Merbach, I. 2007. 'The impact of manuring on nitrogen isotope ratios in cereals: archaeological implications for reconstruction of diet and crop management practices', Journal of Archaeological Science 34, 335-43.

Bogaard, A., Charles, M., Livarda, A., Ergun, M., Filipovic, D. and Jones, G. in press. 'The archaeobotany of mid-later occupation levels at Neolithic Çatalhöyük', in I. Hodder (ed.), Humans and Landscapes of Çatalhöyük: Reports from the 2000-2008 seasons (Monographs of the Cotsen Institute of Archaeology, University of California at Los Angeles; Los Angeles).

Cadogan, J. 1978. 'Pyrgos, Crete, 1970-7', Archaeological Reports 24, 70-84.

Chapouthier, F. and Charbonneaux, J. 1928. Fouilles exécutées à Mallia: premier rapport (1922-1924) (Etudes Crétoises Vol. 1; Paris).

Evans, A.J. 1901. 'Knossos. Summary Report of the Excavations in 1900: I. The Palace', Annual of the British School at Athens 6, 3-70.

Evans, A. 1928, 1935. The Palace of Minos at Knossos, Volumes 2 \& 4 (London).

Evans, J. D., Cann, J. R., Renfrew, A. C., Cornwall, I. W. and Western A. C. 1964. 'Excavations in the Neolithic Settlement of Knossos, 1957-60. Part I', Annual of the British School at Athens 59, 132-240.

Fernald, M.L. and Kinsey, A.C. 1986. Edible Wild Plants of Eastern North America (New York).

Ferrio, J.P., Araus, J.L., Buxó, R., Voltas, J., Bort, J. 2005. 'Water management practices and climate in ancient agriculture: inference from the stable isotope composition of archaeobotanical remains', Vegetation History and Archaeobotany 14, 510-7.

Fiorentino, G. and Solinas, F. 2006. 'Carboni e carporesti dal palazzo di Monastiraki. Indagini paleoambientali e paleoeconomiche', in Kanta, A. and Marazzi, M. (eds.),
Monastiraki I. Campagne 2002-2004 (Quaderni della Fondazione Scavolini, Serie Beni Culturali 4; Naples), 1239.

Follieri, M. 1985. 'Provviste alimentary vegetali in una casa Minoica ad Haghia Triada (Creta)', Annuario della Scuola Archeologica di Atene e delle Missioni Italiane in Oriente 57(41), 165-72.

Fraser, R.A., Bogaard, A., Heaton, T., Charles, M., Jones, G., Christensen, B.T., Halstead, P., Merbach, I., Poulton, P.R., Sparkes, D., Styring, A.K. 2011. 'Manuring and stable nitrogen isotope ratios in cereals and pulses: towards a new archaeobotanical approach to the inference of land use and dietary practices', Journal of Archaeological Science 38, 2790-804.

Galaty, M.L., Nakassis, D. and Parkinson, W.A. (eds.) 2011.

'Forum: Redistribution in Aegean Palatial Societies', American Journal of Archaeology 115(2), 175-244.

Gamble, C. 1981. 'Social Control and the Economy', in Sheridan, A. and Bailey, G. (eds.), Economic Archaeology (Oxford), 215-29.

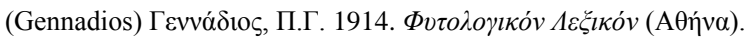
Halstead, P. 1981. 'From determinism to uncertainty: social storage and the rise of the Minoan Palace', in Sheridan, A. and Bailey, G. (eds.), Economic Archaeology (Oxford), 187-213.

Halstead, P. 2004. 'Life After Mediterranean Polyculture: the Subsistence Subsystem and the Emergence of Civilisation Revisited', in Barrett, J.C. and Halstead, P. (eds.), The Emergence of Civilisation Revisited (Sheffield Studies in Aegean Archaeology 6; Oxford), 189-206.

Halstead, P. 2011. 'Redistribution in Aegean palatial societies: terminology, scale, and significance', American Journal of Archaeology 115(2), 229-35.

Halstead, P. and O'Shea, J. 1982. 'A friend in need is a friend indeed: social storage and the origins of social ranking', in Renfrew, C. and Shennan, S. (eds.), Ranking, Resource and 


\section{THE ARCHAEOBOTANY OF NEOLITHIC AND BRONZE AGE CRETE}

Exchange (Cambridge), 92-9.

Hamilakis, Y. 1996. 'Wine, Oil and the Dialectics of power in Bronze age Crete: a review of the evidence', Oxford Journal of Archaeology 15(1), 1-32.

Hamilakis, Y. 1999. 'Food technologies/technologies of the body: the social context of wine and oil production and consumption in Bronze Age Crete', World Archaeology $31(1), 38-54$

Hansen, J.M. 1988. 'Agriculture in the prehistoric Aegean: data versus speculation', American Journal of Archaeology 92, 39-52.

Hansen, J.M. 2000. 'Palaeoethnobotany and palaeodiet in the Aegean region: notes on legume toxicity and related pathologies', in Vaughan, S.J. and Coulson, W.D.E. (eds.), Palaeodiet in the Aegean: Papers from a colloquium held at the 1993 meeting of the Archaeological Institute of America in Washington D.C. (Oxford), 13-27.

Heaton, T.H.E., Jones, J., Halstead, P. and Tsipropoulos, T. 2009. "Variations in the $13 \mathrm{C} / 12 \mathrm{C}$ ratios of modern wheat grain, and implications for interpreting data from Bronze Age Assiros Toumba, Greece', Journal of Archaeological Science 36, 2224-33.

Jones, G. 1984. 'The LMII plant remains', in Popham, M.R. (ed.), The Minoan Unexplored Mansion at Knossos (BSA supp. vol. 17; London), 303-6.

Jones, G. 1987. 'Agricultural Practice in Greek Prehistory', Annual of the British School at Athens 82, 115-23.

Jones, G. 1992. 'Ancient and modern cultivation of Lathyrus ochrus (L.) DC. in the Greek islands', Annual of the British School at Athens 87, 211-7.

Jones, M. and Brown, T. 2007. 'Selection, cultivation and reproductive isolation: a reconsideration of the morphological and molecular signals of domestication', in Vrydaghs, L., Denham, T.P. and Iriarte, J. (eds.), Rethinking agriculture: archaeological and ethnoarchaeological perspectives (One World Archaeology 51; Walnut Creek), 36-49.

Jones, G. and Schofield, A. 2006. 'Evidence for the use of threshing remains at the Early Minoan metallurgical workshop', Hesperia supp. vol. 36, 153-4.

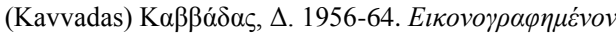

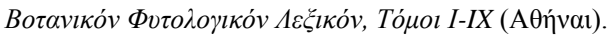
Knappett, C., Evans, T. and R. Rivers, 2011. 'The Theran eruption and Minoan palatial collapse: new interpretations gained from modelling the maritime network', Antiquity 85, $1008-23$.

Kopaka, K. (ed.) 2009. Zakros: Ourania to Froudi: the Cave and the Natural Rockshelters (Athens).

Kopaka, K., and Matzanas, C. 2009. 'Palaeolithic industries from the island of Gavdos, near neighbour to Crete in Greece', Antiquity 83, on-line project gallery: http://www.antiquity.ac.uk/projgall/kopaka321.

Leporrati, L.L. and Impieri, M. 2007. 'Ethnobotanical notes about some uses of medicinal plants in Alto Tirreno Cosentino area (Calabria, Southern Italy)', Journal of Ethnobiology and Ethnomedicine 3: 34.

Livarda, A. 2011. 'Spicing up life in northwestern Europe: exotic food plant imports in the Roman and medieval world', Vegetation History and Archaeobotany 20, 143-64.

Livarda, A. and Kotzamani, G. forthcoming. 'Late Minoan archaeobotanical evidene from Zominthos, Crete'.

Mangafa, M. and Kotsakis, K. 1996. 'A new method for the identification of wild and cultivated charred grape seeds', Journal of Archaeological Science 23, 409-18.

Megaloudi, F. 2006. Plants and Diet in Greece from Neolithic to Classic Periods, The Archaeobotanical Remains (BAR IS 1516; Oxford).

Molloy, B.P.C., Day, J., Bridgford, S.D., Carter, T., Isaakidou, V., Kotzamani, G., Nodarou, E., Milić M., Westlake, P., Klontza-Jaklova, V., Larsson, E., Bates, E. and Hayden, B. (forthcoming). 'Connectivity, complexity and commensality in an East Cretan Village community: the Early Minoan I settlement at Priniatikos Pyrgos'.

Nakassis, D., Parkinson, W.A. and Galaty, M.L. 2011. 'Redistributive economies from a theoretical and crosscultural perspective', American Journal of Archaeology $115(2), 177-84$

Renfrew, A.C. 1972. The Emergence of Civilisation: The Cyclades and the Aegean in the Third Millenium B.C. (London).

Renfrew, J.M. 1972. 'The plant remains', in Warren, P. (ed.), Myrtos: an early Bronze age settlement in Crete (BSA supp. vol. 7; London), 315-7.

Sarpaki, A. 1989. 'Palaikastro. Preliminary Environmental Report', Annual of the British School at Athens 84, 435-6.

Sarpaki, A. 1992a. 'A Palaeoethnobotanical study of the West House, Akrotiri, Thera', Annual of the British School at Athens 87, 219-30. 


\section{ALEXANDRA LIVARDA and GEORGIA KOTZAMANI}

Sarpaki, A. 1992b. 'A palaeoethnobotanical approach. The Mediterranean triad or is it a quartet?', in Wells, B. (ed.), Agriculture in Ancient Greece (Stockholm), 61-76.

Sarpaki, A. 1995. 'Toumba Balomenou, Chaeronia: plant remains from the Early and Middle Neolithic levels', Res Archaeobotanicae (Kiel), 281-300.

Sarpaki, A. 1999. 'The Archaeobotanical study of Tzambakas house, Rethymno, Crete', in Tzedakis, Y. and Martlew, H. (eds.), Minoans and Mycenaeans, Flavours of their Time (Athens), 13-14, 50, 51.

Sarpaki, A. 2000. 'The study of palaeodiet in the Aegean: food for thought', in Vaughan S. and Coulson, J. (eds.) Palaeodiet in the Aegean (Oxford), 115-21.

Sarpaki, A. 2007. 'Résultats archéobotanique préliminaires dans divers secteurs de Malia', Bulletin de Correspondence Hellenique 131, 882-4.

Sarpaki, A. 2009a. 'Knossos, Crete: invaders, "sea-goers”, or previously "invisible", the Neolithic plant economy appears fully-fledged in 9000 BP', in Fairburn, A. and Weiss, E. (eds.), From Foragers to Farmers (Oxford), 220-34.

Sarpaki, A. 2009b. 'The Cave of Ourania to Froudi, Zakros: the archaeobotanical remains', in Kopaka, K. (ed.), Zakros:

Ourania to Froudi: the Cave and the Natural

Rockshelters (Athens), 61-8.

Sarpaki, A. 2012a. 'The taming of an island environment: Crete from dawn to noon (Neolithic to the end of the Bronze Age)', in Cadogan, G., Iacovou, M. Kopaka, K. and Whitley, J. (eds.), Parallel Lives: Ancient Island Societies in Crete and Cyprus (London), 35-45.

Sarpaki, A. 2012b. Re-visiting the visibility of the grape, grape products and by-products: evidence from the Prehistoric Aegean. Interdisciplinaria archaeologica: Natural Sciences in Archaeology 3(1).

Sarpaki, A. (forthcoming). 'A study of the palaeoethnobotanical remains from the site of Kastelli, Chania'.

Sarpaki, A. and Jones, G. 1990. 'Ancient and modern cultivation of Lathyrus clymenum L. in the Greek islands', The Annual of the British School at Athens 85. 363-8.

Sarpaki, A. and Kanta, A. 2011. 'Monastiraki in the Amari region of Crete: some interim archaeobotanical insights

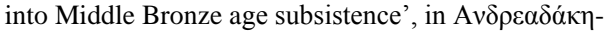

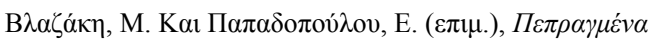

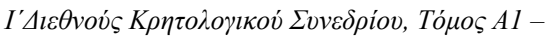

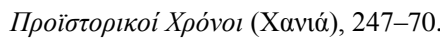

Schlumbaum, A., Tensen, M. and Jaenicke-Després, V. 2008. 'Ancient plant DNA in archaeobotany', Vegetation History and Archaeobotany 17, 233-44.

Schmidt, J. and Stavisky, N. 1983. 'Uses of Thymalaea hirsuta (mitnan) with emphasis on hand papermaking', Economic Botany 37(3), 310-21.

Shay, C.T. and Shay, J.M. with Frego, K.A. and Zwiazek, J. 1995. 'The modern flora and plant remains from Bronze Age Deposits at Kommos', in Shay, C.T. and Shay, J.M. (eds.), Kommos I: The Kommos Region and Houses of the Minoan Town (Princeton), 116-62.

Shelmerdine, C.W. 2008. The Cambridge companion to the Aegean Bronze Age (Cambridge).

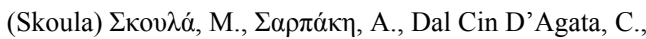

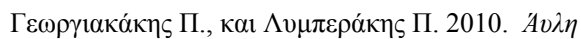

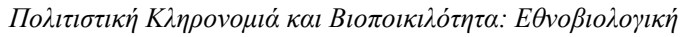

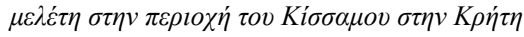
http://www.latsis-foundation.org/files/meletes2010/05.pdf Strasser, T.F., Panagopoulou, E., Runnels, C., Murray, P.,

Thompson, N., Karkanas, P., McCoy, F. and Wegmann, K. 2010. 'Stone Age seafaring from the Mediterranean: evidence from the Plakias region for the Lower Palaeolithic and Mesolithic habitation of Crete', Hesperia 79, 149-90.

Sturtevant, E.L. 1952. Sturtevant's Notes on Edible Plants, edited by U. P. Hedrick (Albany).

Terral, J.-F., Alonso, N., Buxó, R., Chatti, N., Fabre, L.,

Fiorentino, G., Marinval, P., Jorda, G.P., Pradat, B., Rovira, N. and Alibert, P. 2004. 'Historical biogeography of olive domestication (Olea europaea L.) as revealed by geometrical morphometry applied to biological and archaeological material', Journal of Biogeography 31, 6377.

Uphof, J.C.T. 1968. A dictionary of economic plants (Lehre).

Usher, G. 1974. A dictionary of plants used by man (London).

Valamoti, S.M. 2004. Plants and People in Neolithic and Early Bronze Age Northern Greece (British Archaeological Reports 1258; Oxford)

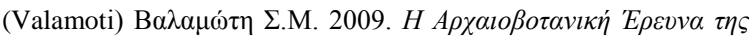

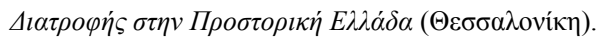

Van der Veen, M. and Fieller, N. 1982. 'Sampling seeds', Journal of Archaeological Science 9, 287-98.

Van der Veen, M. and Jones, G. 2006. 'A re-analysis of agricultural production and consumption: implications for 
understanding of the British Iron Age', Vegetation History and Archaeobotany 15(3), 217-28.

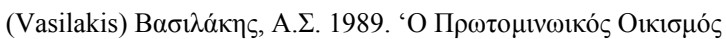

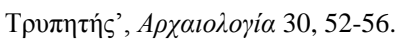

Ventris, M. and Chadwick, J. 1973. Documents in Mycenaean Greek, 2nd edn (Cambridge).

Vickery, K.F. 1936. Food in early Greece (Chicago).

Younger, J.G. and Rehak, P. 2008. 'The material culture of

Neopalatial Crete', in Shelmerdine, C.W. (ed.) The

Cambridge Companion to the Aegean Bronze Age
(Cambridge), 140-64.

Warren, P., Jarman, M.R., Jarman, H.N., Shackleton, N.J. and

Evans, J.D. 1968. 'Knossos Neolithic, Part II', Annual of the British School at Athens 63, 239-76.

Zohary, D. and Hopf, M. 2000. Domestication of plants in the Old World - The origin and spread of cultivated plants in West Asia, Europe and the Nile valley, 3rd edn (Oxford).

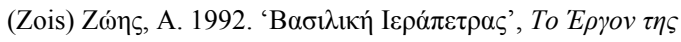

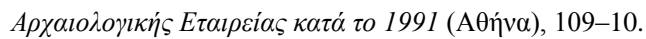

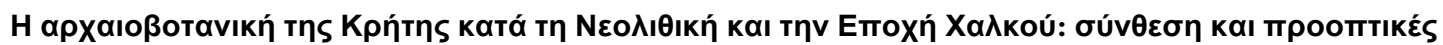

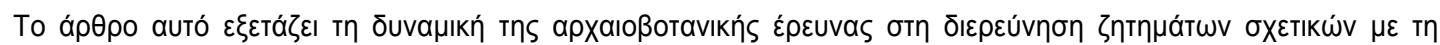

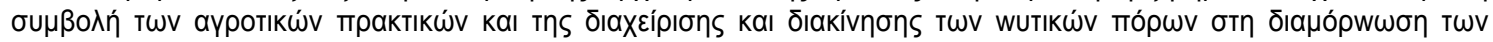

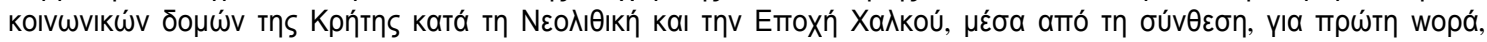

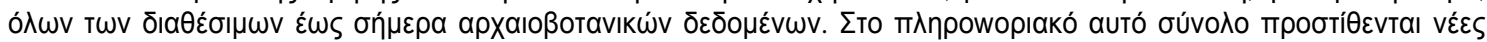

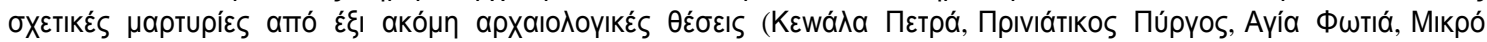

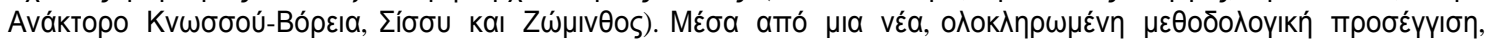

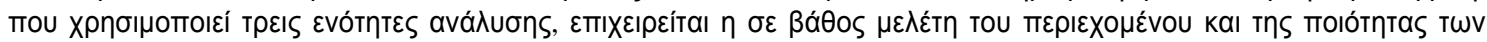

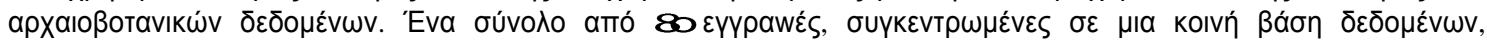

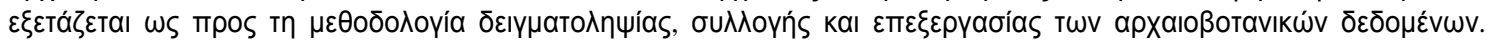

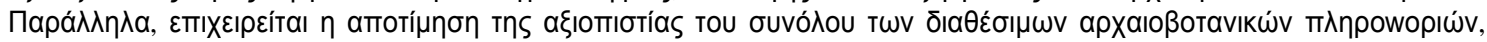

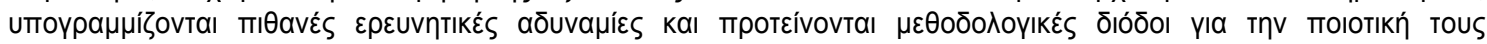

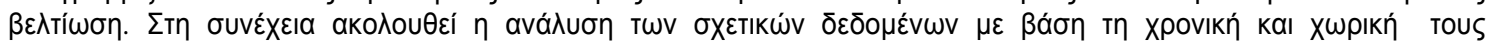

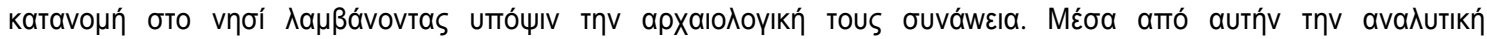

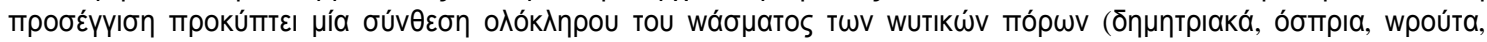

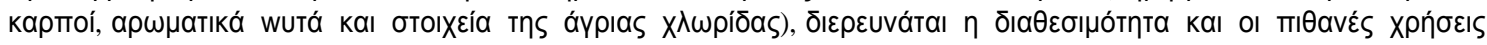

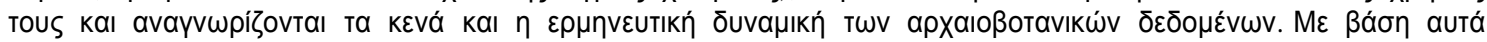

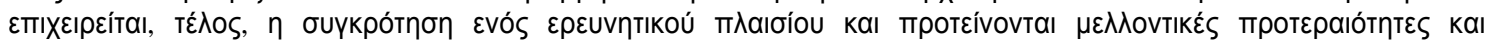

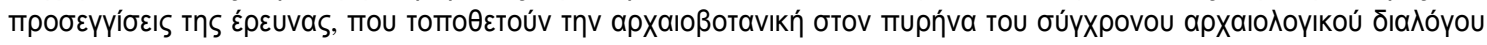

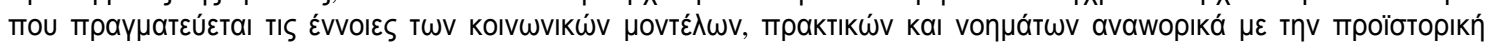
Kрп́тп. 